\title{
Kayanın Jeomekanik Özelliklerinin Metro Tünellerinde Kullanılan Tünel Açma Makinelerinin Performansına Etkisi
}

\section{The Effect of Geomechanical Properties of Rock on the Performance of Tunnel Boring Machines Employed in Metro Tunnels}

\author{
ALi YÜKSEL'1, Nuh BiLGIN² \\ ${ }^{1}$ Yapı Merkezi İnşaat ve San. A.Ş., Hacı Reşit Paşa Sok. No 4A, 34676 Üsküdar, İstanbul \\ 2 IтÜ Maden Fakültesi, Ayazağa Kampüsü, 34469 Maslak, İstanbul \\ Geliș (received) : 26 Aralık (December) 2013 \\ Kabul (accepted) : 04 Mart (March) 2014
}

\section{öz}

Kadıköy Kartal Metro Projesi'nin Kozyatağı ile Kadıköy arasındaki güzergah kesiminde çift tüp șeklinde hat tünelleri, istasyon ve makas yapıları bulunmaktadır. Bu projede, istasyon ve makas tünelleri, değișken kesitlerde olmaları nedeniyle konvansiyonel kazı yöntemi olan Yeni Avusturya Tünelcilik Yöntemi (NATM) ile açıımıștır. Toplam 12.3 km uzunluğundaki hat tünelleri ise hem açık biçim hem de kapalı-basınçlı biçimde çalıșabilen özelliklere sahip TBM makineleri ile açıımıștır. Jeolojik araștırmalar sırasında proje güzergahının Kadıköy ile Kozyatağı arasında kalan kesiminde 107 adet sondaj yapılmıștır. Bu sondajlardan alınan kaya örnekleri üzerinde tünellerdeki kaya ortamın tanımlanmasına yönelik olarak indeks, dayanım ve kaya kütle parametreleri belirlenmiștir. Tünel açma makinelerinin (TBM) kullanılmaya bașlamasından bu yana çeșitli araștırmacılar tarafından kazı performansı ve kaya kütlesinin jeomekanik parametreleri arasındaki ilișkiler konusunda çok sayıda araștırma yapılmıștır. Bu çalıșmada; Kadıköy Kartal Metrosu örneğinde, TBM kullanılarak yapılan tünel açma çalıșmalarında kaydedilen kazı parametreleri ile yine güzergahın bu bölümünde açılmıș sondajlardan elde edilen kaya dayanım parametreleri arasındaki istatistiksel ilișkiler araștıııarak değerlendirilmiștir. Çalıșmada, kayanın jeomekanik parametreleri ile kazı performansı arasında bir, iki ve üç değișkenli regresyon analizleri yapılmıș ve, istatistiksel açıdan anlamlı ilișkiler bulunmuștur. Bulunan ilișkiler yardımıyla benzer kaya koșulları içerisindeki TBM kazılarında jeomekanik büyüklükler kullanılarak kazı performansı önceden belli bir yaklașıklıkla belirlenebilecektir. Benzeri uygulamalardan gelecek verilerin bir veri bankasında toplanması ve değerlendirilmesiyle, yapılacak kestirimlerin hassasiyetinin artacağı muhakkaktır.

Anahtar Kelimeler: EPB, kaya dayanım parametreleri, metro, TBM, tünel, kazı performansı,

\begin{abstract}
Twin railway tunnels, stations and turnout structures exist in the Kozyatağı-Kadıköy section of the Kadıköy-Kartal Metro Project. Stations and switch tunnels were bored by NATM, which is a conventional excavation method, since these structures have varying cross sections. $12.3 \mathrm{~km}$ long track tunnels were excavated with EPB type TBMs that can operate in both open and closed-pressurized modes. During the geological investigation studies, a total of 107 boreholes were drilled between Kozyatağı and Kadıköy. The rock samples obtained from these drillings were examined by considering rock mass indices, compressive strengths and rock mass parameters in order to characterize the rock medium. From the beginning of TBM utilization in tunnel excavations, number of studies were conducted by various researchers for determining the relations between TBM excavation performance and geomechanical rock mass parameters. In this study, the statistical relationships between the recorded excavation data during tunneling and rock strength parameters obtained from drillings were investigated based on the Kadıköy-Kartal Metro
\end{abstract}

A.Yüksel

e-posta: ali.yuksel@ym.com.tr 
Project. Trials with one, two and three variable regression analyses were examined between the geomechanical parameters and excavation performance and statistically significant correlations were obtained. With the help of these regression models, excavation performance can be predicted within an acceptable range from the geomechanical properties for TBM excavations in similar rock conditions.

Keywords: EPBM, excavation performance, metro, tunnel, rock strength parameters, TBM

\section{Giriș}

Günümüzde, özellikle büyük kentlerde metro, kanal ve karayolu gibi altyapı yatırımlarının artmasıyla birlikte, bu yapılar için açılan tünellerde TBM kullanımının giderek arttığı görülmektedir. TBM ile tünel açılması özellikle uzun tünellerde konvansiyonel (örneğin delme patlatma) yöntemlere nazaran daha ekonomik olduğu gibi, ișin bitirilme süresi açısından da avantaj sağlamaktadır. Konvansiyonel yöntemlerde en fazla 5-6 m/gün'lük hızlara erișilebilirken TBM ile açılan tünellerde ortalama 10-15 m/gün düzeylerine, hatta makine kullanım oranının yüksek olarak gerçekleștiği durumlarda $25-60 \mathrm{~m} /$ gün gibi ilerleme hızlarına kadar ulașılabilmektedir. Ancak, TBM makineleri konvansiyonel tünel açma yöntemlerinde kullanılan makine ve ekipmanlara göre birkaç kat daha fazla yatırım gerektirmektedir. TBM yapım teknolojisindeki güncel gelișmeler ve güç koșullarda TBM ile tünel açma deneyiminin artmasına rağmen hala her tür jeolojik koșulda çalıșabilecek olan çok özellikli bir TBM makinesi mevcut değildir. Diğer bir ifadeyle, üretilen TBM'ler jeolojik değișkenlikleri belirli bir ölçüde göğüsleyebilmektedir. Bu nedenle TBM kullanılan tünel projelerindeki jeolojik araștırmaların yeteri düzeyde özenli ve ayrıntılı olarak yapılması, makine imalatının da buradan elde edilen verilerin ıșığı altında gerçekleștirilmesi gerekmektedir.

TBM ile açılacak tünel projelerinde TBM seçimi, diğer bir ifadeyle hangi tipte bir TBM'in kullanılacağı projenin ekonomikliği kadar bașarısı açısından da önemli bir konudur. Uygun olamayan TBM seçimlerinde beklenilen ilerleme hızlarına ulașılamamakta, dolayısıyla proje öngörülen sürede bitirilememektedir. Hatta, TBM'in tamamen kullanım dıșı bırakılıp, kazının konvansiyonel yöntemle tamamlanmak durumunda kalındığı dramatik örnekler de bulunmaktadır (Lui ve Chang, 2005; Lin ve Yu., 2005).
TBM'in kazı performansıyla ilgili ilk çalıșmalar masif kayanın tek eksenli sıkıșma dayanımı, elastisite modülü, sertliği ve așındırıcılığı gibi mekanik özellikleri ile penetrasyon, itme kuvveti ve tork gibi kazı parametreleri üzerinde olmuștur. Bu konudaki araștırmaların bașlıcaları arasında; Kato (1971), Saito (1971), Roxborough ve Philips (1975), Graham (1976), Özdemir (1977),

Snowdown ve diğ. (1982), Nelson (1985), Sanino (1985), Rostami ve Özdemir (1993)'in yaptığı çalıșmalar gösterilebilir (Okubo vd., 1993'den) Bu araștırmaların çoğu kuramsal ve yarı görgül çalıșmalardır.

Yukarıda değinilen çalıșmaların çoğu masif kaya malzemesinin mekanik özelliklerine dayanmakta olup, kaya ortamın tüm jeomekanik özelliklerini içermemektedir. Ancak kayanın yerinde davranıșını, dolayısıyla kazı performansını etkileyen özellikleri arasında eklemlenme, blok boyutu, eklem veya tabaka yönelimi, süreksizliklerin yüzey pürüzlülüğü ve ayrıșma durumu gibi alt özellikler bulunmaktadır. 1965'li yıllarda önerilen kaya kütle sınıflandırmalarından sonra kaya kütlesi özellikleri ile TBM kazı performansı arasındaki ilișkiler de araștırılmaya bașlanmıștır. Barton vd. (1974)'te önerdikleri Q sınıflama sistemine, kayanın tek eksenli sıkıșma dayanımı ve kuvars içeriği, yatay arazi yükü, disk yükü ve disk ömür indeksi parametrelerini de ekleyerek QTBM ölçütü geliștirmiș ve bu parametre ile ilerleme hızı arasındaki ampirik bağıntılar vermiștir (Barton, 2000). Bienawski vd. (2006) de az-çok benzeri parametrelere dayanan "Kaya Kütle Kazılabilirliği” (RME) ölçütünü ortaya koymuș ve İspanya ile Etiyopya'daki tünellerde yapılan gözlemlerinden faydalanarak ortalama ilerleme hızı, tork ve disk yükü arasındaki ilișkileri önermișlerdir. Sapigni vd. (2002) İspanya'daki tünellerde, Hassanpour vd. (2009), Farrokh vd. (2012) ve Oraee vd. (2010) İran'daki tünellerde, Bilgin vd. (1999) ise Türkiye'deki tünellerde 
kayanın jeomekanik özelliklerini esas alan kazı performans tahmin modelllerini geliștirmișlerdir. Geliștirilen bu tahmin modelleri ile penetrasyon, itme kuvveti, döndürme momenti ve ilerleme hızı büyüklükleri için kestirim yapılabilmektedir.

Belli bir kazı dönemi için gerekli süreçler dikkate alındığında, bașlıca kazı, destekleme gibi üretim süreçleri ve TBM ile ilgili bakım, arıza, TBM dıșı; jeolojik, malzeme temini, ölçme, havalandırma, koordinasyon eksikliği vb. nedenlerden kaynaklanan gecikmeler sözkonusudur. Toplam kazı süresi içerisindeki gecikmelerin bir kısmı șantiye öğrenme sürecinde gerek çalıșanların deneyiminin artmasıyla, gerekse teknik sorunların giderilmesiyle büyük ölçüde azaltılabilmektedir.

Bu çalıșma ilk yazarın doktora tez çalıșmasının bir kısmını olușturmakta olup, çalıșmada Kadıköy Kartal Metro Projesi'nde güzergahın bir kısmını olușturan Kadıköy-Kozyatağı arasındaki hat tünellerinde kullanılan EPB-TBM'lerin kazı kayıtları ve sondaj çalıșmalardan elde edilen verileri kullanarak TBM kazı performans parametreleri ile jeomekanik büyüklükler arasındaki ilișkiler araștırılmıștır.

\section{KADIKÖY KARTAL METRO PROJESi}

Kadıköy-Kartal Metrosu Kadıköy'de deniz ulașımı ile bütünleșik olarak șehrin doğu eksenine doğru toplu ulașımı sağlayacak raylı ulașım sistemi olarak planlanmıștır. 21.6 km uzunluğundaki güzergah boyunca 16 istasyon yer almaktadır. Proje, Kadıköy meydanında bulunan istasyon ve buna bağlı kuyruk tünelleri ile bașlamakta ve Yeldeğirmeni semtinin altından ilerleyerek İbrahimağa İstasyonu'na ulașmaktadır. Metro hattı bu istasyonda İstabul'un Avrupa yakasını Anadolu yakasına bağlayan Marmaray projesi ile kesișmektedir. İbrahimağa İstasyonu'ndan sonra E-5 karayolu izdüșümüne gelen hat Aclbadem Köprüsü'nden itibaren güzergah sonuna kadar bu karayoluna yaklașık paralel olarak ilerlemektedir. Metro hattı üzerindeki istasyonlar, sistemin dikine yolcu transferlerinin kolayca yapılabilmesine olanak sağlayacak șekilde E-5 karayolunu kesen kavșak noktalarında veya yakınında planlanmıștır (Șekil1). Tünellerde örtü kalınlığı 8-60 m arasında değișmekte olup ortalama kalınlık 30 m civarındadır. Tünel derinliği, topoğrafyaya bağlı olmakla beraber, bir yandan metro sisteminin en yüksek tırmanma eğimine, diğer yandan da istasyon derinliğine bağlı olarak değișmektedir.

\section{TBM ILE TÜNEL AÇMA ÇALIȘMALARI}

Tünel kazısı sırasındaki yeraltısuyu seviyesi değișkenliklerinin ve yüzeyde oturma meydana getiren zemin kayıplarının minimum düzeyde kalmasını sağlaması, açılan tünelin ön döküm kaplamalar ile hemen desteklenmesine olanak vermesi dolayısıyla hat tünellerinin açılmasında, "Pasa Basıncı Dengelemeli Kazı Makinesi (EPBTBM) kullanılması öngörülmüștür. Ancak kesit boyutları hat tünellerinden farklı olan makas ve istasyon tünelleri NATM yöntemi ile açılmıștır.

Kadıköy ile Kozyatağı İstasyonları arasındaki hat tünellerinin kazısına, daha uygun ișletme koșullarına sahip olması dolayısıyla Kozyatağı İstasyonu'ndan bașlanmıș ve Kadıköy yönüne doğru ilerlenmiștir. TBM'lerden ilki Haziran 2007'de sahaya gelmiș ve montajı yapılarak sol hatta 14 Ağustos 2007'de, değeri ise sağ hatta 18 Ekim 2007'de de kazıya bașlamıștır. Çizelge 1'de açılan tünel uzunlukları ve tünel çalışmalarının kronolojik gelişimi özetlenmiştir.

Tünellerin TBM ile yaklașık yarı mesafeye kadar açılmasından sonra makinelerin destek sistemleri Ünalan İstasyonu'nun hemen yakınındaki karayolu kavșak kolu içerisindeki alanda açılmıș olan S5A ve S5B kuyularına aktarılmıștır. Böylece nakliye süresi kısaldığı gibi tașıma ekipmanları ve diğer destek sistemlerinden de tasarruf etme yoluna gidilmiștir. Sağ hatta TBM ile 6075.8 m tünel kazılarak toplam 4084 adet öndöküm beton destek halkası yerleștirilmiș, sol hatta ise 6305.0 m tünel kazılarak toplam 4223 adet destek halkası yerleștirilmiștir. Kazı ișleri TBM'lerin Kadıköy İstayonu'nun ilerisindeki M1 makasına gelmesiyle, sağ hatta 11.06.2010'da, sol hatta ise 09.07.2010'da tamamlanmıștır.

Her iki hattaki tünelde de birbirinin benzeri EPB tipi TBM kullanılmıștır (Çizelge 2). Bu makineler hem "açık biçim", hem "kapalı biçim" hem de "basınçlı biçim"de kazı yapabilecek șekilde üretilmiștir. Açık biçimde, kazılan malzeme kazı odasının merkezinde bulunan bantlı konveyörle 


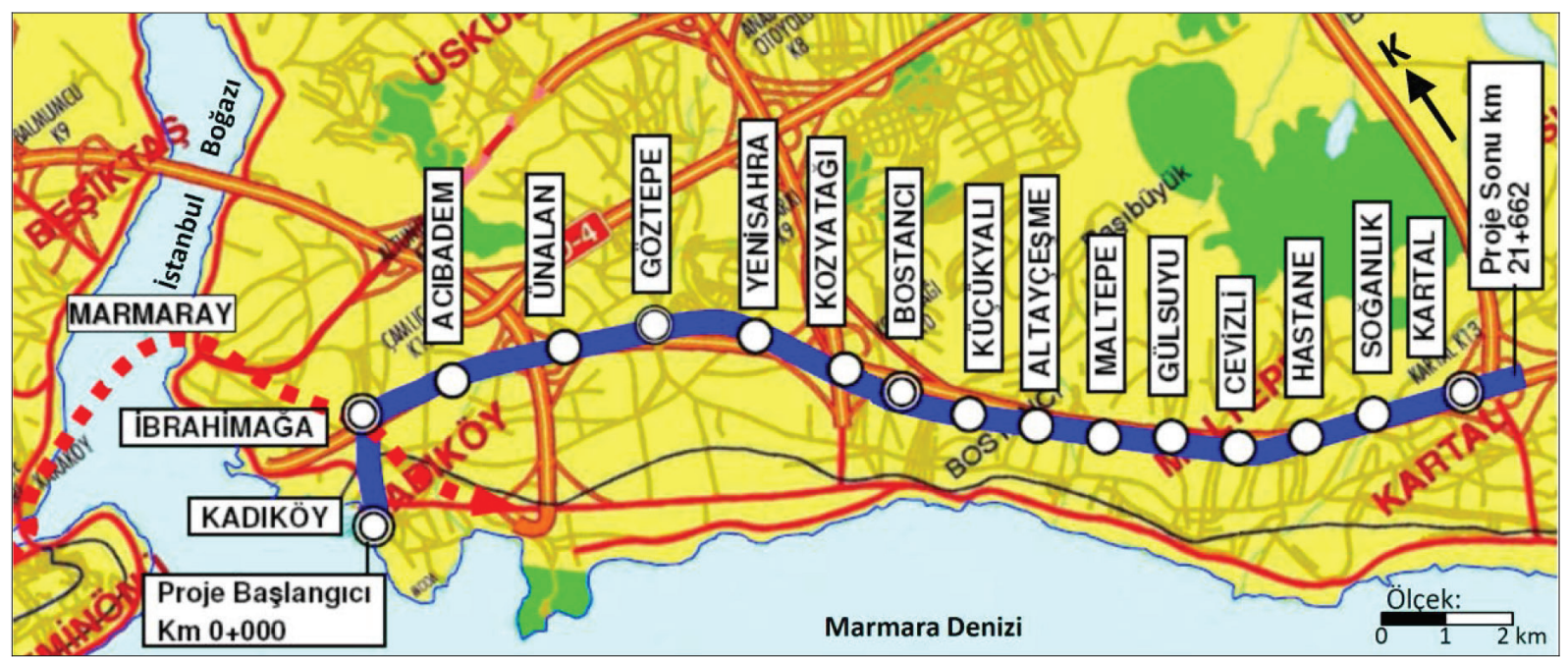

Şekil 1. Kadıköy - Kartal Metrosu güzergahının yerleșimi ve istasyonlar (Yüksel vd., 2006)

Figure 1. Kadıköy - Kartal Metro alignment and layout of stations (Yüksel et al., 2006)

Çizelge 1.Kozyatağı-Kadıköy arasında TBM ile tünel açma çalıșmaları (Yüksel, 2013)

Table 1. Tunneling works with TBM between Kadıköy and Kartal Stations (Yüksel, 2013)

\begin{tabular}{lcc}
\hline \multicolumn{1}{c}{ Açıklama } & Sağ Hat (Hat 1) & Sol Hat (Hat 2) \\
\hline Güzergah uzunluğu (m) & 8072.4 & 7978.4 \\
Toplam TBM tünel uzunluğu ( m) & 6075.7 & 6266 \\
Öndöküm kaplama halkası adedi & 4084 & 4223 \\
Kazı bașlangıç tarihi & 18.10 .2007 & 14.08 .2007 \\
Kazı bitim tarihi & 09.07 .2010 & 11.06 .2010 \\
Fiili kazı süresi (gün) & 795 & 875 \\
Toplam süre (gün) & 995 & 1032 \\
Ortalama kazı hızı (m/gün) & 10.0 & 9.3 \\
\hline
\end{tabular}

alınmaktadır. Kapalı biçim ve basınçlı biçimde ise kazılan malzeme, kazı odasından burgulu konveyör ile alınmaktadır.

Tünelin desteklenmesinde iç çapı $5.70 \mathrm{~m}$, kalınlığı $30 \mathrm{~cm}$ ve genișliği $1.50 \mathrm{~m}$ olan $5+1$ segment dizilimine sahip üniversal tipte ön döküm betonarme halka kullanılmıștır.

\section{METRO GÜZERGAHININ JEOLOJISI VE KAZILAN FORMASYONLARIN JEOMEKANIK ÖZELLIKLERi}

TBM kazıları sırasında kazı sırasına göre bașlıca Kartal, Baltalimanı, Tuzla ve Trakya formasyonlarından geçilmektedir (Șekil 2).
Kartal Formasyonu, sarımsı kahverengi, laminaIı, seyrek olarak silttașı ve kumtașı ara tabakalı, fosilli șeyl ve kireçtașı seviyelerinden olușmaktadır. Șeyl tabakalarının bulunduğu kısımlar zayıf dayanımlı, çatlaklı-çok sık çatlaklı olmasına karșın, kireçtașı tabakalarının ağırlıkta olduğu kısımları ise daha az çatlaklı ve göreli olarak daha yüksek dayanımlıdır (Ketin, 1992; Seymen, 1995).

Kartal Formasyonu güzergahta Hasanpașa Köprüsü $(\mathrm{km} \mathrm{3+800)}$ civarından bașlamakta, Bostancı deresinde $(\sim \mathrm{km} 11+000)$ yerini arkozlardan olușan Kurtköy formasyonuna bırakmaktadır.

Tuzla Formasyonu bașlıca yumrulu kireçtașlarından olușmakta ve bunlar çok ince tabakalı- 
Çizelge 2.Kullanılan EPB-TBM'lerin teknik özellikleri (Yüksel, 2013 )

Table 2. Specifications of the EPB-TBMs employed in tunnel excavations (Yüksel, 2013)

\begin{tabular}{|c|c|}
\hline Teknik özellik & Büyüklük \\
\hline Kazı çapı & $6.57 \mathrm{~m}$ \\
\hline Kalkan çapı & $6.54 \mathrm{~m}$ \\
\hline Kalkan boyu & $8.23 \mathrm{~m}$ \\
\hline TBM gövde ağırlığı & 350 ton \\
\hline Toplam kurulu güç & $2100 \mathrm{~kW}$ \\
\hline Kesici kafa gücü & $1260 \mathrm{~kW}$ \\
\hline \multirow{2}{*}{ Kesici kafa torku } & 5200 kNm @ 3.1 rpm \\
\hline & 2912 kNm @ 5.5 rpm \\
\hline Toplam itme kuvveti & 42575 kN @ 350 bar \\
\hline İtme silindiri sayısı ve stroku & 32 adet, $2.2 \mathrm{~m}$ \\
\hline Disk keski sayısı & 38 adet ( 6 adet çiftli) \\
\hline Disk keski çapı ve en büyük yükü & 17 inch, 267 kN \\
\hline Diskler arası mesafe & $90 \mathrm{~mm}$ \\
\hline Tırnak keski sayısı & 62 adet \\
\hline Burgulu konveyör uzunluğu / çapı & $12 \mathrm{~m} / 0.7 \mathrm{~m}$ \\
\hline
\end{tabular}

laminalı çamurtașları ile ardalanmalı olarak bulunmaktadır.

Baltalimanı Formasyonu olarak adlandıılan formasyon ise fosfat yumrulu ve çörtlü șeyllerden olușmaktadır. Bu formasyon, çok ince tabakalı yapıya sahip olması nedeniyle çok kıvrımlı karakteristik bir yapı gösterir (Ketin, 1991; Seymen, 1995). Tuzla ve Baltalimanı Formasyonu güzergahta sadece Acıbadem İstasyonu çevresinde (km 2+800 - km 3+300) bulunmaktadır.

Trakya Formasyonu, yeșilimsi-gri, yer yer çakıltașı ve daha çok kumtașı-silttașı-kiltașı ardalanması șeklinde gözlenmektedir. Orta-sağlam kaya özelliğindeki Trakya Formasyonu, çoğunlukla üç veya daha fazla eklem takımını içermektedir. Eklem yüzeylerinin arası kil, kalsit ve yer yer kuvars dolguludur (Ketin, 1991; Seymen, 1995). Trakya Formasyonu, proje bașlangıcı olan $\mathrm{km} 0+000$ ile $\mathrm{km} 2+800$ arasında yer almaktadır.

Güzergahtaki alüvyon dolgular, yüzey topoğrafyasının daha düșük kota sahip olduğu vadilerde akan derelerin tașıdığı malzemelerden olușmuștur. Aluvyon dolgularıyla sadece $\mathrm{km}$ $3+850$ ile km 4+100 arasında karșılașılmaktadır. Güzergahta geçilen formasyonların jeomekanik özellikleri Çizelge 3'te verilmiștir. Çizelge 3'ten anlașılacağı üzere Trakya Formasyonu ile Kartal Formasyonu-Zon A'da karșılașılan kaya türlerinin kaliteleri az çok biribirine benzer nitelikte olup, "zayıf" kaya sınıfında yer almaktadırlar. Buna karșın Kartal FormasyonuZon B "orta-iyi" kaya kütle kalitesine sahip bir kayadır.

Güzergah boyunca rastlanılan kayaçlarda, tektonik hareketlerin yönlerine bağlı olarak genellikle üç veya daha fazla eklem takımı gelișmiștir. Bunun yanısıra, formasyonlarda, tektonik hareketler sonucu olușan așırı deformasyonların kıvrımlanma olayı ile karșılanamadığı zonlarda büyük kırık, fay ve ezilme zonları meydana gelmektedir (Kodamanoğlu, 1977). Genellikle volkanik sokulumlarla birlikte gözlenen bu tür yapılarla güzergah boyunca oldukça sık karșılașılmaktadır. 


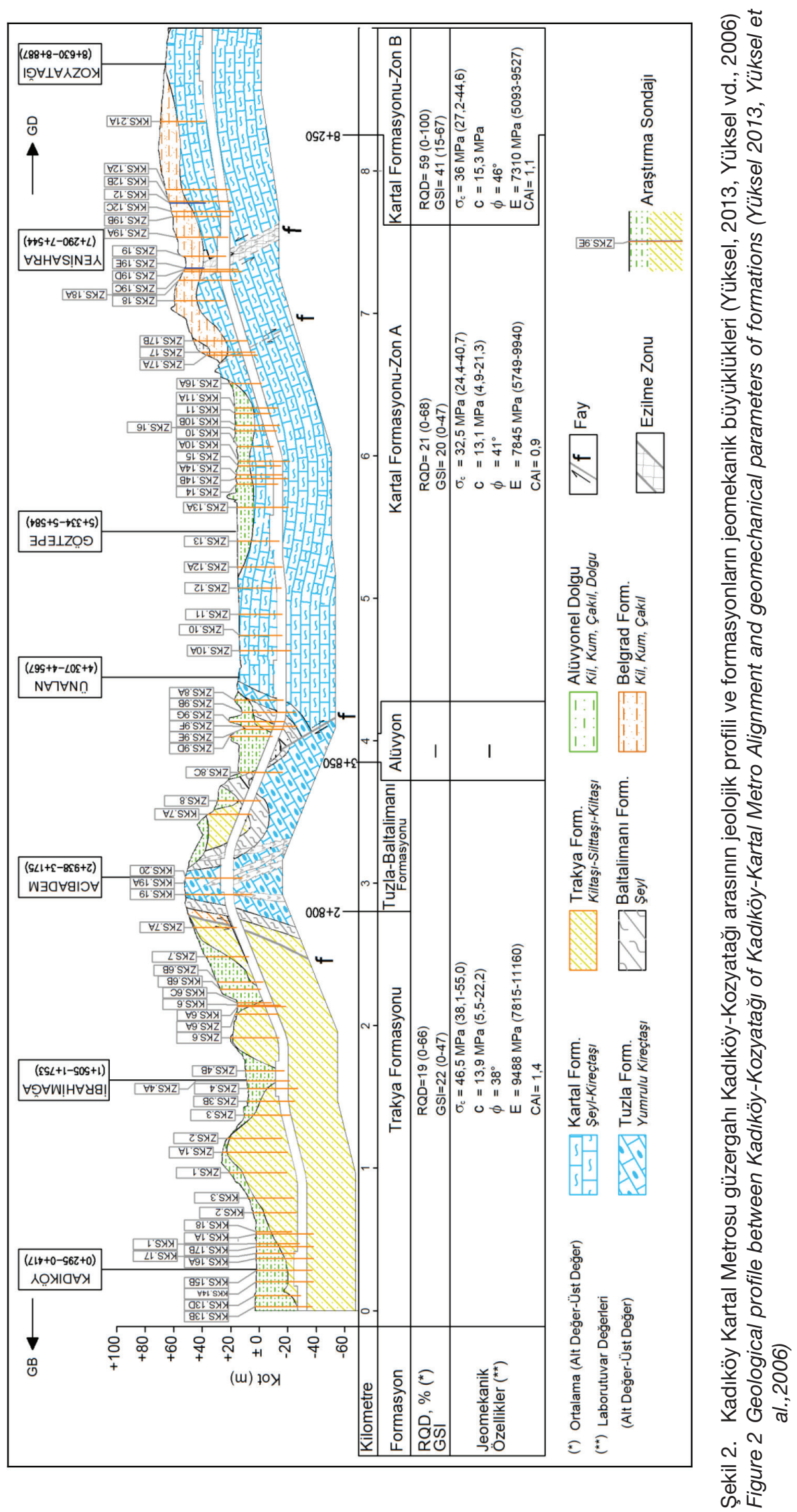


Çizelge 3.Jeolojik formasyonların jeomekanik özellikleri (Yüksel, 2013 )

Table 3. Geomechanical properties of the geological formations (Yüksel, 2013)

\begin{tabular}{|c|c|c|c|c|c|c|c|c|c|c|}
\hline \multirow[t]{2}{*}{ Jeomekanik Özellik } & \multirow[t]{2}{*}{ (Birim) } & \multicolumn{3}{|c|}{$\begin{array}{c}\text { Trakya } \\
\text { Formasyonu (*) }\end{array}$} & \multicolumn{3}{|c|}{$\begin{array}{c}\text { Kartal Formasyonu } \\
\text { Zon A }\end{array}$} & \multicolumn{3}{|c|}{$\begin{array}{c}\text { Kartal Formasyonu } \\
\text { Zon B }\end{array}$} \\
\hline & & $N$ & $x$ & $D A$ & $N$ & $x$ & $D A$ & $N$ & $x$ & $D A$ \\
\hline $\begin{array}{ll}\text { Kaya } & \text { kalite } \\
\text { göstergesi, } R Q D\end{array}$ & (\%) & 740 & 19.2 & $(0-100)^{\prime}$ & 328 & 21 & $(0-100)$ & 158 & 58 & $(0-100)$ \\
\hline $\begin{array}{l}\text { Jeolojik dayanım } \\
\text { indeksi, GSI }\end{array}$ & $(-)$ & 740 & 22.3 & $(0-100)$ & 328 & 20 & $(0-70)$ & 158 & 41 & $(0-100)$ \\
\hline Birim hacim ağırlık, $\gamma$ & $\begin{array}{l}(\mathrm{kN} / \\
\left.\mathrm{m}^{3}\right)\end{array}$ & 101 & 26.5 & $(20.6-27.6)$ & 42 & 26.1 & $(22.2-27.5)$ & 55 & 26.9 & $(23.5-28.5)$ \\
\hline Gözeneklilik, n & (\%) & 37 & 4.85 & $(0.37-27.5)$ & 19 & 4.24 & $(0.95-10.5)$ & 19 & 1.01 & $(0.25-3.23)$ \\
\hline $\begin{array}{l}\text { Tek eksenli sıkıșma } \\
\text { dayanımı, } \sigma_{c}\end{array}$ & (MPa) & 72 & 46.6 & $(1.9-155.3)$ & 39 & 32.6 & $(1.1-94.5)$ & 51 & 52.7 & $(7.7-158.3)$ \\
\hline Çekme dayanımı, $\sigma_{t}$ & (MPa) & 32 & 6.4 & $(1.1-14.0)$ & 20 & 4.8 & $(1.8-9.1)$ & 35 & 7.7 & $(0.22-17.9)$ \\
\hline $\begin{array}{l}\text { Elastisite modülü, } E \\
(x 1000)\end{array}$ & (MPa) & 44 & 9.49 & $(0.67-20.3)$ & 28 & 7.8 & $(1.2-25.1)$ & 24 & 10.8 & $(4.5-18.8)$ \\
\hline Poisson oranı, v & $(-)$ & 31 & 0.27 & $(0.18-0.42)$ & 23 & 0.30 & $(0.18-0.38)$ & 23 & 0.30 & $(0.21-0.38)$ \\
\hline Kohezyon, c & (MPa) & 8 & 13.8 & $(4.0-32.5)$ & 5 & 13.1 & $(4.3-19.8)$ & 6 & 15.1 & $(5.4-28.0)$ \\
\hline $\begin{array}{l}\text { İçsel sürtünme açısı, } \\
\varnothing\end{array}$ & $\left({ }^{\circ}\right)$ & 8 & 38 & $(27-51)$ & 5 & 40.5 & $(32-45)$ & 6 & 45 & $(40-54)$ \\
\hline $\begin{array}{l}\text { Cherchar așındırıcılık } \\
\text { indeksi, CAI }\end{array}$ & $(-)$ & 18 & 1.37 & $(0.5-2.5)$ & 13 & 0.94 & $(0.5-2.3)$ & 26 & 1.79 & $(0.5-3.5)$ \\
\hline
\end{tabular}

$\left({ }^{\star}\right)$ : Tuzla ve Baltalimanı Formasyonlarına ait veriler az sayıda olduğundan Trakya Formasyonu ile birlikte değerlendirilmiștir. N: Veri Sayısı, X: Ortalama, DA: Değișim aralığı

\section{TBM KAZI PARAMETRELERI İLE FORMASYONLARIN JEOMEKANIK ÖZELLIKLERI ARASINDAKi iLIȘKILER}

\section{Sondaj Verisi}

Kadıköy-Kartal Metrosu güzergahıyla ilgili jeolojik araștırmalar kapsamında Kozyatağı ile Kadıköy İstasyonları arasında kalan kısımda değișik așamalarda olmak üzere, toplam $3.525 \mathrm{~m}$ uzunluğunda, 107 adet araștırma sondajı yapılmıștır (Yüksel vd., 2005, Yüksel vd., 2006). Bu araștırmaların ilk așamasında yapılan sondajlara ait detaylı jeomekanik veriler yapılan laboratuvar deneyleriyle belirlenmiștir. Daha sonraki așamalarda yapılan sondajlar daha çok jeolojik yapının ayrıntılandırıması ve kesinleștirilmesi amacına yönelik olup bütçe ve zamanla ilgili ekonomik gerekçeler nedeniyle bu sondajlardan alınan örnekler üzerinde çoğu jeomekanik deney yapılmamıștır. Diğer taraftan, bazı sondajlar NATM ile açılan istasyon ve makas tünellerine isabet etmekte, bazı sondajlar ise güzergahtan uzakta bulunmaktadır. Bu nedenle bu kısımlara isabet eden sondajlar, bu değerlendirmenin dıșında tutulmuștur. TBM güzergahına isabet eden 28 sondaja ait kaya kütlesi parametreleri ve kaya dayanım özellikleri Çizelge 4'te verilmiștir. Bu çizelgede, kaya kalite göstergesi $(R Q D)$ ve jeolojik dayanım indeksi (GSI) (Sönmez ve Ulusay, 2002) gibi kayanın süreksizlik özellikleri ve kaya kütle kalitesini temsil eden parametrelerinin yanı sıra, dayanım parametreleri olan, tek eksenli sıkıșma dayanımı, çekme dayanımı, elastisite modülü, ve așındırıcılık indeksi gibi indeks özelliklerinin ortalamaları da belirtilmiștir.

\section{TBM Kayıtları ve Değerlendirme Yöntemi}

TBM kazısı sırasında kaydedilen kazı parametrelerinin değerlendirilmesinde, sondaj noktasının tüneldeki izdüșümüne karșı gelen yerin yaklașık 10 kazı adımı öncesi ve sonrasına ait ( 30 m) TBM kazı kayıtları dikkate alınmıștır (Șekil 3). 
Çizelge 4. Kozyatağı-Kadıköy arasında yapılan sondajlar ve bu sondajlara ilișkin jeomekanik veriler.(Yüksel, 2013) Table 4. Site investigation boreholes drilled between Kozyatağı - Kadıköy alignment and obtained geomechanical data associated with these boreholes (Yüksel 2013)

\begin{tabular}{|c|c|c|c|c|c|c|c|c|}
\hline $\begin{array}{c}\text { Sondaj } \\
\text { No }\end{array}$ & km & $\begin{array}{c}\text { Derinlik } \\
\text { (m) }\end{array}$ & $\begin{array}{c}\text { RQD } \\
(\%)\end{array}$ & GSI & $\begin{array}{c}\text { Tek eksenli } \\
\text { sıkıșma dayanımı } \\
\sigma_{c}(\mathrm{MPa}) \\
\end{array}$ & $\begin{array}{c}\text { Çekme } \\
\text { dayanımı, } \\
\sigma_{t}(\mathrm{MPa}) \\
\end{array}$ & $\begin{array}{c}\text { Elastisite } \\
\text { modülü, E, } \\
\text { (MPa) }\end{array}$ & $\begin{array}{l}\text { Așındırıcılık } \\
\text { indeksi,CAl }\end{array}$ \\
\hline ZKS.21A & $8+347$ & 31.0 & 44.2 & 32.7 & 49.15 & 6.3 & 11250 & 2.3 \\
\hline KKS.12A & $7+867$ & 45.0 & 8.6 & 13.5 & 1.38 & - & - & - \\
\hline KKS.12 & $7+772$ & 25.0 & 0.0 & 10.0 & - & - & - & - \\
\hline ZKS.19B & $7+679$ & 39.7 & 10.1 & 30.0 & 9.40 & - & - & - \\
\hline ZKS.18 & $7+087$ & 34.0 & 27.4 & 19.9 & 20.93 & 5.70 & 5625 & 0.7 \\
\hline ZKS.17 & $6+725$ & 37.7 & 5.0 & 7.5 & 36.90 & 8.40 & 8200 & - \\
\hline ZKS.16A & $6+506$ & 22.0 & 17.4 & 21.4 & 37.90 & 5.00 & - & - \\
\hline ZKS.15 & $5+927$ & 29.7 & 44.4 & 31.4 & 54.05 & - & 20900 & 2.3 \\
\hline ZKS.14 & $5+800$ & 29.0 & 1.6 & 10.0 & 12.10 & - & - & - \\
\hline ZKS.12 & $5+071$ & 30.0 & 1.8 & 15.2 & 38.95 & 5.30 & 11250 & 1.0 \\
\hline ZKS.11 & $4+887$ & 30.0 & 1.8 & 28.0 & 20.50 & - & - & 0.5 \\
\hline ZKS.10 & $4+738$ & 30.0 & 36.0 & 37.2 & 22.63 & 4.75 & 5835 & 1.0 \\
\hline ZKS.10A & $4+632$ & 36.0 & 32.5 & 27.7 & 42.90 & 5.60 & 6400 & - \\
\hline ZKS.8 & $3+578$ & 30.0 & 0.0 & 15.0 & - & - & - & \\
\hline KKS.7A & $3+484$ & 30.0 & 19.1 & 33.2 & 14.20 & 4.45 & 2950 & 1.1 \\
\hline KKS.19 & $2+921$ & 46.5 & 1.0 & 11.0 & 21.90 & - & - & - \\
\hline ZKS.7A & $2+690$ & 30.0 & 15.8 & 22.3 & 62.80 & 4.85 & 7600 & - \\
\hline ZKS.7 & $2+484$ & 34.0 & 1.7 & 15.1 & - & - & - & 2.0 \\
\hline ZKS.6B & $2+306$ & 32.0 & 0.0 & 10.9 & - & - & - & - \\
\hline KKS.6 & $2+144$ & 15.1 & - & - & - & - & - & 1.1 \\
\hline ZKS.6A & $2+081$ & 30.0 & 5.6 & 18.9 & 25.20 & 9.90 & 6100 & - \\
\hline ZKS.6 & $1+915$ & 34.0 & 13.7 & 27.3 & - & - & - & 2.1 \\
\hline ZKS.3 & $1+372$ & 32.0 & 1.6 & 15.0 & 57.30 & - & 8270 & - \\
\hline ZKS.2 & $1+210$ & 38.0 & 1.0 & 7.0 & 17.87 & 1.10 & 2700 & 0.5 \\
\hline ZKS.1A & $1+111$ & 45.5 & 2.4 & 6.7 & - & 4.20 & - & - \\
\hline ZKS.1 & $0+968$ & 40.0 & 14.3 & 26.0 & 45.83 & 4.00 & 6023 & 2.1 \\
\hline KKS.3 & $0+791$ & 32.0 & 54.7 & 37.8 & 19.80 & 3.20 & - & 1.0 \\
\hline KKS.2 & $0+687$ & 30.0 & 8.7 & 30.0 & 28.30 & 1.20 & 8070 & 1.2 \\
\hline
\end{tabular}




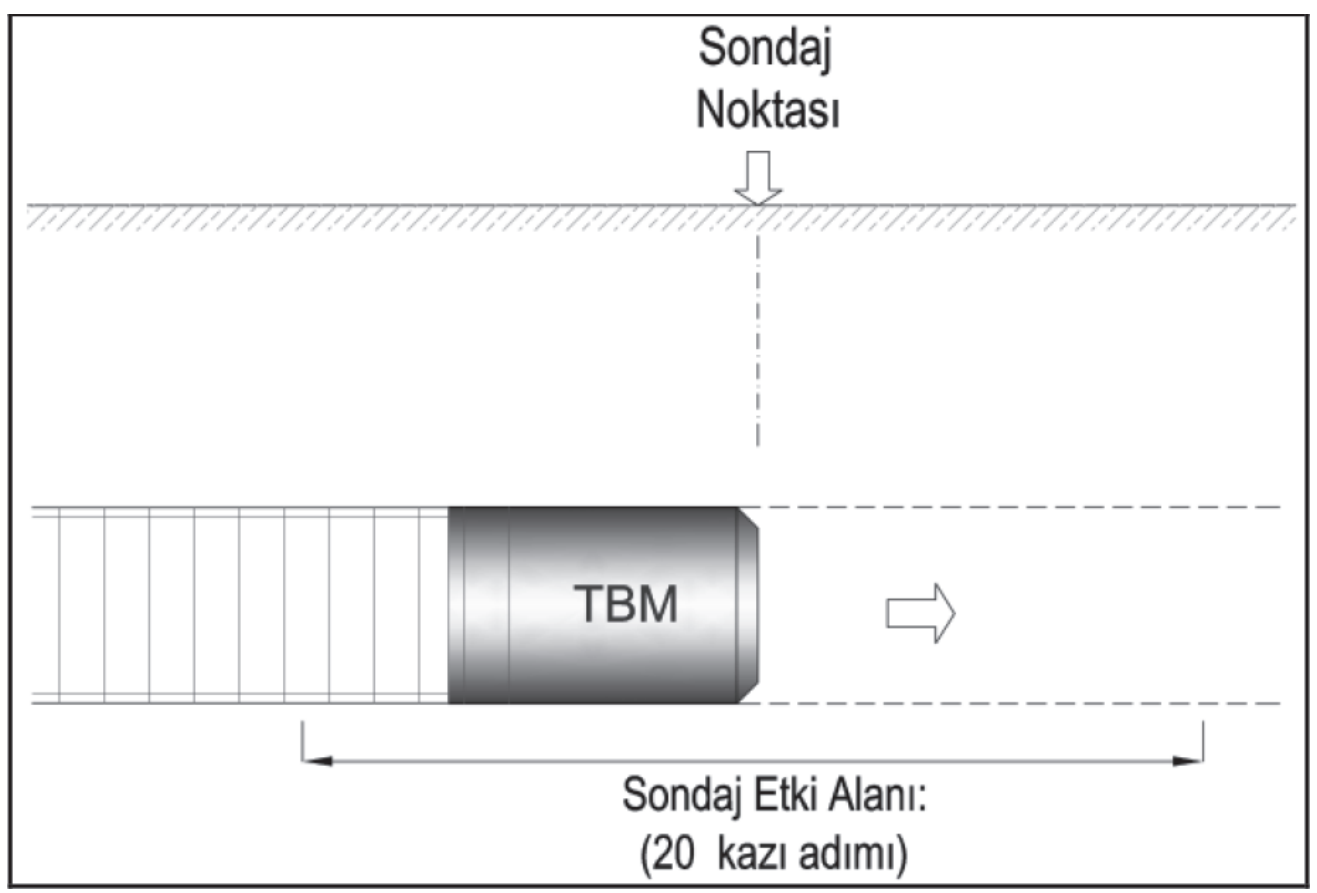

Şekil 3. Sondaj noktasına göre TBM parametrelerinin değerlendirme aralığı

Figure 3. Excavation range of TBM parameters respect to boring location

- Toplam itme kuvveti/penetrasyon oranı, $k N / \frac{T F}{p}$
(mm/rev)

- Tork/Penetrasyon oranı, $(k N . m) /(m m / r e v) \quad \frac{T}{p}$

- Kesme katsayısı,

$C C=\frac{F R}{F N}$

- Delinebilirlik indeksi, $(k N / d i s k) /(m m / d e v)$

$B I=\frac{T F}{N_{c^{*}} \cdot f l \cdot p}$

- Güç tüketimi, kW

$$
P=2 \pi \frac{r p m}{60} \cdot T
$$

- Yerinde spesifik enerji, $k W h / m 3$

$S E=k \frac{P}{I C R}$

- Anlık kazı hızı, $m 3 / h$

$I C R=0,06 \cdot$ p.rpm.A

Bu kayıtlara ait kazı performansı parametreleri yukarıda verilen eșitliklerden hesaplanmıș ve ilgili sondaj noktası için tek değer ile temsil edilmesi için 20 adetlik kazı verisinin ortalaması alınmıștır.
Burada FR disk bașına yuvarlanma kuvveti ( $k N$ / disk), $F N$ disk bașına normal kuvvet ( $k N /$ disk) $N_{c}$ disk sayısı, fl sürtünme kaybı katsayısı; yaklașık olarak $f l=1.2$ değeri 
alınmaktadır. rpm kesici kafanın dakikadaki dönüș sayısı, $k$ diskten kayaya aktarılan kesme enerjisi transferi oranı; $\mathrm{k}=0.8 \sim 0.9$ olarak verilmektedir, $A$ tünel kesit alanıdır $\left(\mathrm{m}^{2}\right)$.

Sondaj yerlerindeki jeomekanik özellikler ve yaklașık 30 m'lik kazı aralığına karșılık gelen TBM kazı parametrelerinin ortalama değerleri Çizelge 5 ve 6'da verilmiștir.

\section{Kazı Performansı için Regresyon Modelleri}

Yapılan regresyon analizlerinde bağımlı değișken ( $y$ ) olarak; "toplam itme kuvveti / penetrasyon" oranı (TF/p), "tork / penetrasyon" oranı $(T / p)$, penetrasyon $(p)$, güç tüketimi $(P)$, spesifik enerji (SE), anlık kazı hızı (ICR) büyüklükleri ele alınmıștır. Bağımsız değișkenler ise tek, iki ve üç değișken olarak regresyon modellerinde așağıda tartıșılan ve Çizelge 7 ve 8'de gösterilen kombinasyonlarda kullanılmıștır.

\section{İstatistiksel Değerlendirme}

Kazılan tünel ortamının jeomekanik özellikleri ile TBM kazı parametreleri arasındaki regresyon eșitliklerinin istatistiksel olarak anlamlı olup olmadığını belirlemek için korelasyon katsayılarına bakılmakla birlikte, sadece korelasyon katsayısı bunun için yeterli olmamaktadır. Değișimlerin istatistiksel açıdan anlamlı olup olmadığı "kararını" olușturabilmek için "F testi" yapmak gerekmektedir. Incelenen bir regresyon ifadesi için test istatistiği katsayısı olan $F_{\text {test }}$ sayısı, korelasyon katsayısı ve serbestlik derecelerine bağlı olarak;

$$
F_{\text {test }}=\frac{\frac{r^{2}}{k-1}}{\frac{1-r^{2}}{n-k}}
$$

ifadesinden belirlenmektedir.

Burada; $r$ tekli ve çoklu regresyonda elde edilen korelasyon katsayısı, $k$ bağlı değișken $(y)$ ve serbest değișkenlerin $\left(x_{1}, x_{2}, . ., x_{n}\right)$ toplam sayısı ve $n$ regresyon analizinde bulunan veri takımı (gözlem hacmi) sayısıdır.

$F_{\text {test }}$ değeri, belirli bir anlamlılık düzeyi $(\alpha)$ ve serbestlik dereceleri için $F$ tablosundan bulunan
$F_{c r t}$ kritik değerinden daha büyük çıkarsa söz konusu basit (tek değișkenli) veya çok değișkenli regresyon ifadesindeki serbest $(y)$ ve bağlı değișkenler $(x 1, x 2, . ., x n)$ arasında istatistiksel olarak anlamlı bir ilișki (korelasyon) bulunduğu şeklinde karar verilmektedir. $F_{c r t}$ değerinin belirlenmesi için anlamlılık düzeyi $\alpha=0.05$ seçilmiș olup, serbestlik derecesi ise $v_{1}=k-1, v_{2}=n-k$ ile belirlenmektedir.

Korelasyonların $F_{\text {test }}$ değerleri Microsoft Office Excel programı kullanılarak elde edilmiștir. Tek değișkenli, iki ve üç değișkenli regresyonlar için "kabul" veya "ret" kararına ilișkin sonuçları așağıdaki tablolarda gösterilmiștir (Çizelge 9-11).

Tek değișkenli regresyonlar arasında TBM kazı parametreleri ile fazla sayıda anlamlı ilișkiyi elastisite modülü (E), Cerchar Așındırıcılık İndeksi (CAl), "tek eksenli sıkıșma dayanımı $\times$ Cerchar Așındırıcılık İndeksi" [ $\sigma_{c^{*}}$ CAl] ve kaya kütlesi kesilebilirlik indeksi (RMCl) özelliklerinin sağladığı belirlenmiștir. Buna karșın, ortamın kaya kütle kalitesini ifade eden (GSI) ve çekme dayanımı $\left(\sigma_{\imath}\right)$ gibi bağımsız değișkenler anlamlı ilișkiler vermemiștir. Diğer taraftan, bağımlı değișken olarak spesifik enerji (SE) ve anlık kazı oranı (ICR) en fazla sayıda anlamlı ilișki veren özellikler olmuștur. Yine penetrasyon $(p)$ ve güç tüketimi $(P)$ ile jeomekanik özellikler arasında anlamlı ilișki bulunamamıștır.

Regresyon ilișkileri arasında istatistiksel açıdan anlamlı olarak; iki bağımsız değișkenli olan 25 ve üç bağımsız değișkenli olan 10 adet eșitlik belirlenmiștir. Kazı parametreleri ile jeomekanik özellikler arasındaki iki bağımsız değișkenli korelasyonlarda en fazla anlamlı ilișkiyi yine elastisite modülü sağlamakta, bunu kaya kütlesi kesilebilirlik indeksi izlemektedir. Üç bağımsız değișkenli regresyon ifadelerinde de yine benzer bir durum sözkonusudur.

Daha önce de belirtildiği gibi Kadıköy-Kozyatağı arasında 107 adet sondaj yapılmıș olmasına karșın, bunlardan sadece 28'i TBM kullanılarak açılan tünel güzergahına isabet etmektedir. Diğer taraftan tünel güzergahı üzerinde bulunan sondajlarda ise sınırlı sayıda laboratuvar deneyi yapılabilmiștir. Dolayısıyla sınırlı sayıdaki bu deneylerin kazı ortamını temsil etmekte kısmen yetersiz kalabileceği gözardı edilmemelidir. Diğer 
m

\begin{tabular}{|c|c|c|c|c|c|c|c|c|c|c|c|c|c|c|c|c|c|c|}
\hline & 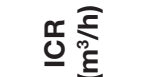 & $\begin{array}{l}\text { @ } \\
\infty \\
\stackrel{\sigma}{+}\end{array}$ & 웃 & $\begin{array}{l}\text { ○ी } \\
\stackrel{\infty}{ }\end{array}$ & ட̊. & $\hat{\infty}$ & ㅎ. & $\bar{\varphi}$ & $\hat{\theta}$ & 守 & 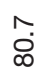 & ח̊ & $\begin{array}{l}\text { ๙ } \\
\text { న }\end{array}$ & $\stackrel{\infty}{\infty}$ & $\stackrel{\Gamma}{\infty}$ & $\begin{array}{l}\infty \\
\infty\end{array}$ & $\begin{array}{l}0 \\
\mathbb{N}\end{array}$ & $\stackrel{m}{N}$ \\
\hline & 山 & $\stackrel{\circ}{\circ}$ & $\stackrel{+}{\circ}$ & $\stackrel{\infty}{\Gamma}$ & @o & $\check{\sigma}$ & $\stackrel{m}{N}$ & $\stackrel{⿱}{\leftarrow}$ & $\stackrel{\oplus}{\leftarrow}$ & $\stackrel{\varphi}{\circ}$ & $\bar{\sigma}$ & ڤె & $\stackrel{\text { ? }}{N}$ & $\infty$ & $\stackrel{+}{\circ}$ & $\stackrel{\overbrace{}}{\wedge}$ & $\stackrel{\infty}{N}$ & $\stackrel{+}{\sim}$ \\
\hline & a & 穴 & 守 & $\frac{⿱}{6}$ & $\begin{array}{l}\text { vִ } \\
\text { ஸे }\end{array}$ & ণ़ & $\begin{array}{l}\infty \\
0 \\
0 \\
\end{array}$ & $\begin{array}{l}\infty \\
\dot{0} \\
\dot{1} \\
\infty\end{array}$ & $\begin{array}{l}\infty \\
\stackrel{N}{N}\end{array}$ & స్ & $\stackrel{n}{N}$ & ¿ & 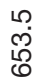 & 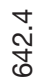 & $\stackrel{0}{N}$ & 용 & $\begin{array}{l}m \\
\stackrel{n}{1} \\
\text { in }\end{array}$ & 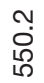 \\
\hline & ن & ণ़ & $\stackrel{\square}{\check{0}}$ & $\frac{\sigma}{\sigma}$ & N̦ & ণ़ & $\frac{\sigma}{\circ}$ & $\stackrel{\mathscr{N}}{0}$ & $\frac{0}{\circ}$ & $\begin{array}{l}\stackrel{0}{N} \\
0\end{array}$ & ָ̃ & 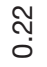 & $\frac{\infty}{0}$ & 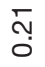 & 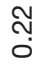 & $\frac{\infty}{\sigma}$ & $\frac{0}{5}$ & 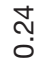 \\
\hline$\frac{\widehat{m}}{0}$ & 을 喪突 & ָ̃ & ヘ்̃ & $\frac{\sim}{i n}$ & $\begin{array}{l}\stackrel{0}{\text { j}} \\
\stackrel{m}{\leftarrow}\end{array}$ & $\begin{array}{l}\stackrel{0}{1} \\
\stackrel{1}{\leftarrow}\end{array}$ & $\begin{array}{l}\stackrel{0}{\square} \\
\frac{j}{\square}\end{array}$ & @ִ & Г্ & 吕 & 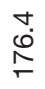 & $\underset{\infty}{\frac{0}{\infty}}$ & $\begin{array}{l}\stackrel{0}{\oplus} \\
\stackrel{\mathscr{D}}{\Gamma}\end{array}$ & 总 & ๙্ं & $\begin{array}{l}\text { N } \\
\text { N } \\
\end{array}$ & $\frac{1}{5}$ & 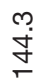 \\
\hline$\sum_{\frac{1}{0}}^{\frac{1}{0}}$ & 는 톨 롫 & 웅 & लై & ஜேं & $\begin{array}{l}m \\
\stackrel{0}{0} \\
\stackrel{\infty}{N}\end{array}$ & 芦 & $\begin{array}{l}\text { ナे } \\
\text { ه্ }\end{array}$ & $\frac{n}{\infty}$ & 尔 & Na & 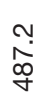 & ষ্ণ & $\frac{n}{n}$ & $\stackrel{\dot{v}}{\hat{\theta}}$ & 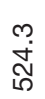 & 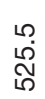 & 灾 & $\begin{array}{l}\text { @ } \\
\text { ळ্ }\end{array}$ \\
\hline$\stackrel{\pi}{\bar{\sigma}}$ & ○ छે छे & $\stackrel{+}{\infty}$ & I & $\stackrel{9}{m}$ & $\begin{array}{l}\stackrel{\varphi}{0} \\
\stackrel{0}{-}\end{array}$ & $\stackrel{\text { g }}{\stackrel{\sim}{\leftarrow}}$ & $\hat{\oplus}$ & $\stackrel{\mathscr{O}}{\stackrel{\sim}{\sim}}$ & $\mp$ & $\stackrel{ָ}{\stackrel{N}{\sim}}$ & ஸ़ & $\stackrel{\circ}{\stackrel{\oplus}{\leftarrow}}$ & $\stackrel{\oplus}{\stackrel{\varphi}{\leftarrow}}$ & 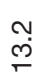 & $\begin{array}{l}\stackrel{\infty}{\sim} \\
\stackrel{\sim}{\sim}\end{array}$ & $\hat{m}$ & $\stackrel{N}{N}$ & $\stackrel{\check{N}}{\sim}$ \\
\hline 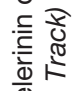 & $\vdash \overline{\underline{\xi}}$ & 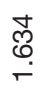 & $\frac{\hat{m}}{\stackrel{i}{N}}$ & $\frac{\text { on }}{\text { ì }}$ & 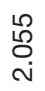 & Na & 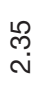 & $\begin{array}{l}\bar{N} \\
\stackrel{N}{N}\end{array}$ & $\begin{array}{l}\hat{m} \\
\stackrel{0}{\rho} \\
\stackrel{N}{N}\end{array}$ & 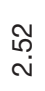 & $\begin{array}{l}\stackrel{L}{2} \\
\stackrel{\text { N }}{N}\end{array}$ & 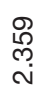 & $\begin{array}{l}\infty \\
\infty \\
\stackrel{N}{N}\end{array}$ & $\begin{array}{l}\text { S? } \\
\text { ì }\end{array}$ & $\begin{array}{l}\text { P్ల } \\
\text { ले } \\
\text { in }\end{array}$ & $\begin{array}{l}\hat{\infty} \\
\stackrel{0}{0} \\
\text { ì }\end{array}$ & 吕 & 景 \\
\hline 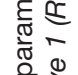 & 崩文 & \begin{tabular}{l}
$\infty$ \\
$\varnothing$ \\
\hdashline
\end{tabular} & \begin{tabular}{l}
0 \\
\multirow{2}{N}{} \\
$a$
\end{tabular} & হ & $\stackrel{\text { }}{\stackrel{\text { J }}{\forall}}$ & ஜ్ & $\begin{array}{c}\infty \\
\substack{\infty \\
1}\end{array}$ & $\begin{array}{l}m \\
\stackrel{5}{5} \\
\infty\end{array}$ & 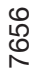 & 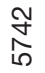 & ల్లి & लृ & ஜ & $\frac{\text { I }}{6}$ & $\begin{array}{l}\mathscr{ల} \\
\varnothing ్ ర\end{array}$ & $\frac{\infty}{\frac{1}{1}}$ & $\frac{10}{\sqrt{0}}$ & 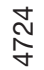 \\
\hline$\sum_{0}^{x} \mathbb{\sigma}$ & ষ্ঠ & $\stackrel{m}{\sim}$ & ' & $\hat{o}$ & $\stackrel{\circ}{-}$ & مْ & $\stackrel{\circ}{-}$ & ' & 1 & $\stackrel{\circ}{\text { N }}$ & 1 & $\check{F}$ & 1 & $\bar{\sim}$ & ' & $\stackrel{10}{0}$ & $\stackrel{\circ}{r}$ & $\stackrel{\sim}{\Gamma}$ \\
\hline $\begin{array}{l}\frac{\pi}{0} \\
\frac{\mathbb{\omega}}{5} \\
\frac{d}{\sigma}\end{array}$ & $w \frac{\bar{\Phi}}{\sum}$ & $\begin{array}{l}\stackrel{\circ}{\stackrel{N}{N}} \\
\stackrel{T}{\leftarrow}\end{array}$ & 1 & 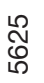 & $\begin{array}{l}\stackrel{\circ}{\stackrel{N}{N}} \\
\stackrel{\Gamma}{\leftarrow}\end{array}$ & & $\begin{array}{l}\stackrel{2}{\infty} \\
\infty \\
\infty \\
\infty\end{array}$ & $\begin{array}{l}\text { ○ } \\
\text { ఫै }\end{array}$ & 1 & 1 & 1 & 1 & $\frac{8}{6}$ & ' & 只 & 오 & ' & $\begin{array}{l}\text { O } \\
\text { I } \\
\infty\end{array}$ \\
\hline $\begin{array}{l}\frac{\pi}{\pi} \\
\frac{\pi}{v} \frac{0}{\pi}\end{array}$ & $0^{+} \sum^{+\frac{\bar{\pi}}{\Sigma}}$ & $\stackrel{m}{0}$ & ' & in & ڤె & & 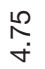 & $\stackrel{\varphi}{\circ}$ & ' & ' & ' & ' & बூ & 1 & 1 & $\check{\check{r}}$ & ஸे & $\check{\Gamma}$ \\
\hline 敢 ब & $0^{\circ} \frac{\bar{\pi}}{\underline{0}}$ & $\frac{10}{\frac{0}{9}}$ & ' & $\begin{array}{l}\text { Oి } \\
\text { ᄋे }\end{array}$ & $\begin{array}{l}\stackrel{\text { ڤn }}{\infty} \\
\infty\end{array}$ & ஜ̊ & $\begin{array}{l}\mathscr{\Re} \\
\stackrel{N}{N}\end{array}$ & 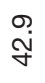 & 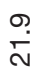 & ' & ' & 1 & $\stackrel{\sim}{\sim}$ & 1 & $\stackrel{n}{\text { N }}$ & $\begin{array}{l}\stackrel{N}{\infty} \\
\stackrel{N}{-}\end{array}$ & $\stackrel{\infty}{\stackrel{\infty}{\Gamma}}$ & $\stackrel{\substack{\infty \\
\infty}}{\stackrel{\infty}{\sim}}$ \\
\hline ఫ & क্ & กิ่ & $\stackrel{\circ}{\circ}$ & $\begin{array}{l}\text { क़ } \\
\text { के }\end{array}$ & مָ & $\stackrel{\circ}{\infty}$ & N̦ & ì & $\stackrel{\circ}{\leftarrow}$ & 5 & $\stackrel{\circ}{\circ}$ & 1 & $\begin{array}{l}\infty \\
\infty \\
\infty\end{array}$ & 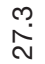 & 10 & $\stackrel{\circ}{\wedge}$ & $\stackrel{\infty}{\stackrel{\infty}{\infty}}$ & ○्ं \\
\hline บे & oิ & $\underset{\sim}{\stackrel{v}{g}}$ & $\stackrel{0}{\circ}$ & ন্ & $\stackrel{\infty}{r}$ & $\stackrel{\infty}{r}$ & ఱ) & $\begin{array}{l}n \\
\text { กิ }\end{array}$ & $\stackrel{\circ}{r}$ & 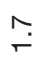 & $\stackrel{\circ}{\circ}$ & 1 & $\stackrel{\varphi}{\varphi}$ & $\stackrel{r}{\oplus}$ & $\stackrel{\varphi}{r}$ & $\stackrel{\circ}{r}$ & 苦 & $\hat{\infty}$ \\
\hline 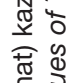 & 芯眊 & న & ర్ర & 年 & $\stackrel{5}{\infty}$ & న్ & స్ & ஜి & $\begin{array}{l}\stackrel{\mathfrak{m}}{\sim} \\
\stackrel{\sim}{N}\end{array}$ & ஜ్లి & $\frac{10}{n}$ & $\begin{array}{l}\text { @્ } \\
\text { ల్ }\end{array}$ & ஜ্ & $\frac{\infty}{\frac{\infty}{\sigma}}$ & 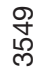 & $\begin{array}{l}\hat{1} \\
0 \\
0\end{array}$ & ભొ & ষ্ণ \\
\hline $\begin{array}{l}\mathbb{D} \\
\mathscr{D} \\
-\mathbb{D}\end{array}$ & 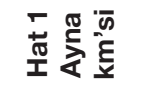 & $\begin{array}{l}\text { f } \\
\text { ले } \\
+\end{array}$ & $\begin{array}{l}\stackrel{N}{N} \\
\stackrel{+}{N}\end{array}$ & $\begin{array}{l}\hat{1} \\
\text { o } \\
+ \\
+\end{array}$ & $\begin{array}{l}\overline{1} \\
0 \\
+ \\
1\end{array}$ & $\begin{array}{l}\text { N } \\
\infty \\
\infty \\
+ \\
+\end{array}$ & $\begin{array}{l}\infty \\
\stackrel{\infty}{\rho} \\
\stackrel{+}{+}\end{array}$ & 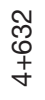 & $\begin{array}{l}\text { ণ } \\
\stackrel{+}{+} \\
\text { N }\end{array}$ & 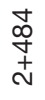 & $\begin{array}{l}\stackrel{8}{0} \\
\stackrel{+}{+} \\
\stackrel{+}{N}\end{array}$ & $\frac{\text { \& }}{+}$ & $\begin{array}{l}\bar{\infty} \\
0 \\
\stackrel{+}{N}\end{array}$ & $\begin{array}{l}\frac{10}{6} \\
\stackrel{+}{+}\end{array}$ & $\begin{array}{l}\stackrel{N}{N} \\
\stackrel{N}{+} \\
+\end{array}$ & $\begin{array}{l}\stackrel{0}{+} \\
\stackrel{+}{+} \\
\pm\end{array}$ & $\begin{array}{l}5 \\
\text { T } \\
+ \\
0\end{array}$ & $\begin{array}{l}1 \\
\infty \\
0 \\
+ \\
0\end{array}$ \\
\hline 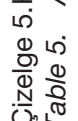 & " & 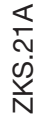 & $\begin{array}{l}\stackrel{v}{c} \\
\dot{c} \\
\frac{y}{x}\end{array}$ & $\begin{array}{l}\frac{\infty}{c} \\
\text { ci } \\
\frac{y}{N}\end{array}$ & $\begin{array}{l}\frac{N}{c} \\
\frac{D}{N}\end{array}$ & 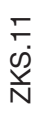 & $\begin{array}{l}\text { 옴 } \\
\text { ஸे } \\
\text { ㄴ }\end{array}$ & $\begin{array}{l}\overleftarrow{5} \\
\text { c) } \\
\frac{0}{N}\end{array}$ & $\begin{array}{l}\frac{\sigma}{c} \\
\text { c) } \\
\frac{1}{x}\end{array}$ & $\begin{array}{l}\hat{c} \\
\stackrel{y}{N}\end{array}$ & $\begin{array}{l}0 \\
0 \\
\stackrel{+}{ } \\
\frac{N}{N}\end{array}$ & $\begin{array}{l}0 \\
\dot{D} \\
\vec{Y}\end{array}$ & $\begin{array}{l}\varangle \\
\emptyset \\
\text { ç } \\
\frac{1}{N}\end{array}$ & $\begin{array}{l}0 \\
\text { ஸे } \\
\stackrel{N}{N}\end{array}$ & $\begin{array}{l}m \\
\text { Dे } \\
\frac{1}{N}\end{array}$ & 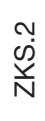 & \begin{tabular}{l}
$n$ \\
Dे \\
\multicolumn{1}{r}{}
\end{tabular} & $\begin{array}{l}\sim \\
\text { Dे } \\
\underline{Y}\end{array}$ \\
\hline
\end{tabular}




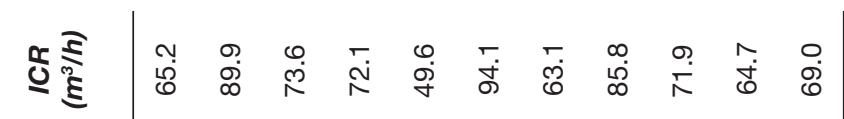

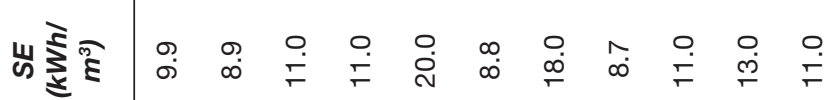
吸等

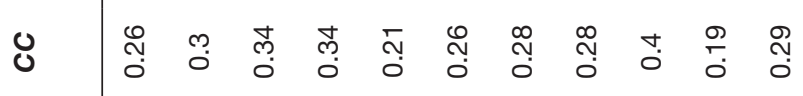

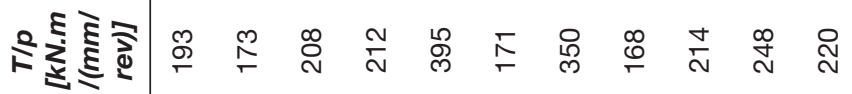

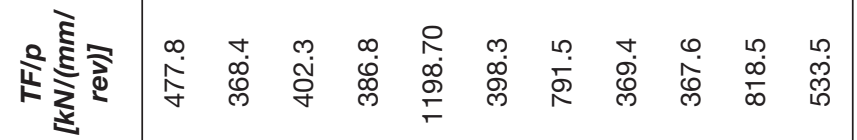
< ํㅗㄹ

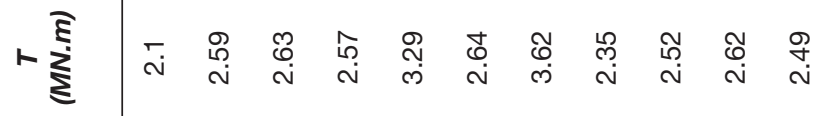
皮弪

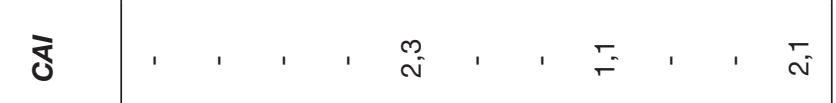

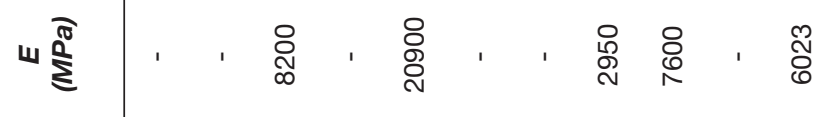
ए

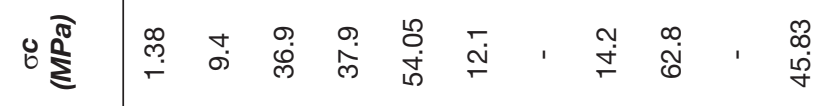

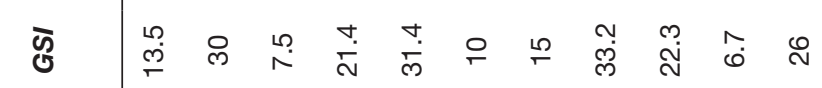
ठ্রి

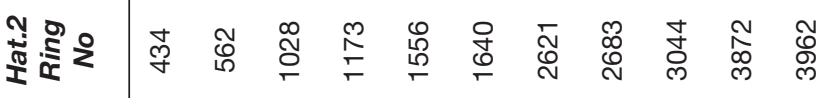

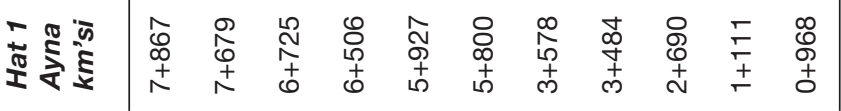

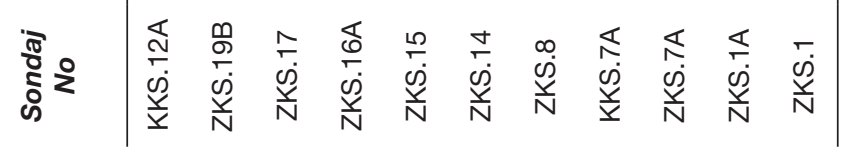


Çizelge 7. İki bağımsız değișkenli regresyon analizlerinde incelenen bağımsız değișken kombinasyonları Table 7. Combination of two undependent variables investigated in regression analyses

\begin{tabular}{|c|c|c|c|c|c|c|c|c|c|c|}
\hline 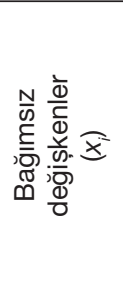 & 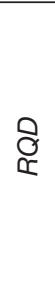 & क् & 乌్ & $\omega$ & $\frac{b}{0^{\circ}}$ & ర্ঠ & $\underset{0^{0}}{\stackrel{\mathrm{N}}{\mathrm{N}}}$ & $\begin{array}{l}\overline{0} \\
0^{\circ}\end{array}$ & 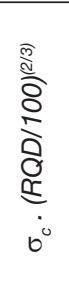 & 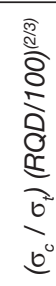 \\
\hline 1 & $x_{1}$ & & $x_{2}$ & & & & & & & \\
\hline 2 & & $x_{1}$ & $x_{2}$ & & & & & & & \\
\hline 3 & $x_{1}$ & & & & $x_{2}$ & & & & & \\
\hline 4 & & & & $x_{1}$ & $x_{2}$ & & & & & \\
\hline 5 & $x_{1}$ & & & $x_{2}$ & & & & & & \\
\hline 6 & & $x_{1}$ & & $x_{2}$ & & & & & & \\
\hline 7 & $x_{1}$ & & & & & & $x_{2}$ & & & \\
\hline 8 & & $x_{1}$ & & & & & $x_{2}$ & & & \\
\hline 9 & $x_{1}$ & & & & & $x_{2}$ & & & & \\
\hline 10 & & & & $x_{1}$ & & & & $x_{2}$ & & \\
\hline 11 & & & & $x_{1}$ & & & & & $x_{2}$ & \\
\hline 12 & & & & $x_{1}$ & & & & & & $x_{2}$ \\
\hline 13 & & & & & & $x_{1}$ & & & $x_{2}$ & \\
\hline 14 & & & & & & $x_{1}$ & & & & $x_{2}$ \\
\hline
\end{tabular}

taraftan bu sondajlardan bazıları da tünel güzergahı civarında, ancak hat ekseninden değișik mesafelerde olmak üzere 15-20 m'den daha uzakta bulunmaktadır. TBM kazı parametreleri ile bazı jeomekanik özellikler arasında istatistiksel olarak anlamlı ilișki elde edilememesinin nedeni bașlıca bu hususlar ile açıklanabilir.

\section{TBM KAZI PARAMETRELERI ILE JEOMEKANIK BÜYÜKLER ARASINDAKI TEK VE ÇOK DEĞișKENLI KORELASYONLAR}

Incelenen tek değișkenli 60 regresyon eșitliği arasında 21'i anlamlı ilișkiler olarak değerlendirilmiștir. Anlamlı bulunan ilișkilerden yüksek korelasyonlara sahip olan ilk 10'u Șekil 4-13'de gösterilmiștir (Yüksel 2013).

Bu çalıșma kapsamında, farklı kombinasyonlarda olușturulan 84'er adet regresyon ifadesi içerisinde ise iki değișkenli 25 adet, üç değișkenli 10 adet regresyon ifadesi istatistiksel olarak anlamlı bulunmuștur (Yüksel, 2013) Makaledeki sayfa sınırlaması gözönünde bulundurularak bu ifadelerden sadece istatistiksel olarak anlamlı bulunan ve korelasyon katsayıları en yüksek olan 10'ar tanesi așağıda verilmiștir (Çizelge 12-13).

\section{SONUÇLAR VE DEĞERLENDIRME}

Bu çalıșmada, Kadıköy Kartal Metrosu kazısı örneğinde TBM performans parametreleri ile sondajlardan alınan karot örnekleri kullanılarak tayin edilen jeomekanik özellikler arasındaki ilișkiler araștırılmıștır. Jeolojik araștırma çalıșmaları sırasında yapılan 28 adet sondaja ilișkin RQD, GSI gibi parametreler ile yine bu sondajlardan alınmıș örnekler üzerinde laboratuvarda yapılan tek eksenli sıkıșma dayanımı, çekme dayanımı, elastisite modülü ve așındırıcılık indeksi gibi özellikler değerlendirmeye alınmıștır.

İstatistiksel korelasyon modellerinde toplam itme kuvveti, tork, penetrasyon gibi TBM kazı 
Çizelge 8.Üç bağımsız değișkenli regresyon analizlerinde incelenen bağımsız değișken kombinasyonları Table 8 Combination of three undependent variables investigated in regression analyses

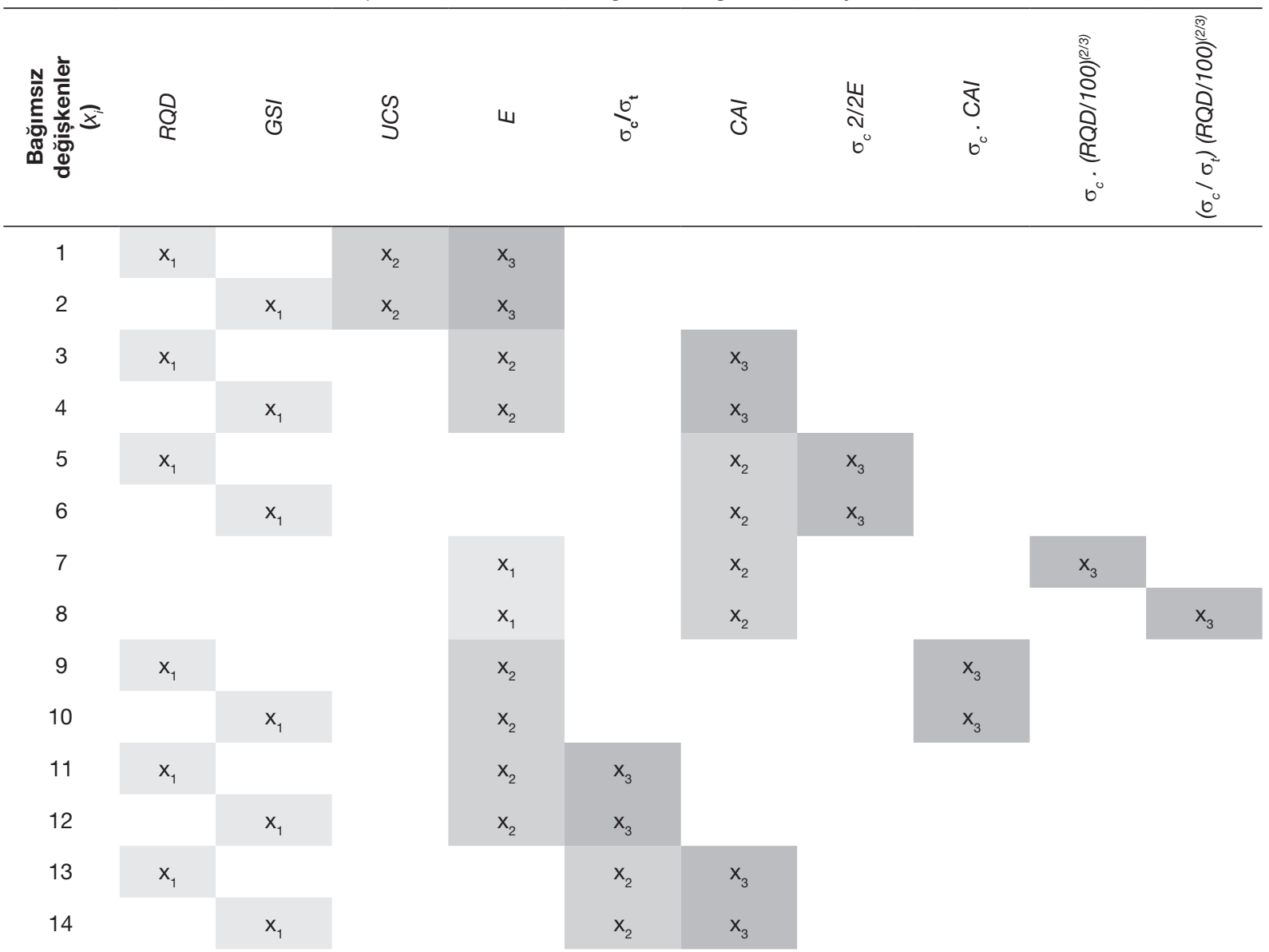

Çizelge 9.Tek bağımsız değișkenli regresyon eșitliklerinde istatistiksel olarak anlamlı bulunan bağımlı ve bağımsız değișkenler Table 9. Statistically significant dependent and undependent variables in the regression equations with single independent variable

\begin{tabular}{|c|c|c|c|c|c|c|c|c|}
\hline $\begin{array}{l}x \\
\downarrow\end{array}$ & $y \rightarrow$ & $\mathrm{TF} / \mathrm{p}$ & $T / p$ & $p$ & $\mathbf{P}$ & SE & ICR & Toplam \\
\hline$R Q D$ & & & & & & & & - \\
\hline GSI & & & & & & & & - \\
\hline$\sigma_{c}$ & & & $\sqrt{ }$ & & & $\sqrt{ }$ & $\sqrt{ }$ & 3 \\
\hline$E$ & & $\sqrt{ }$ & $\sqrt{ }$ & & & $\sqrt{ }$ & $\sqrt{ }$ & 4 \\
\hline$\sigma_{c}^{2} / 2 E$ & & & & & & $\sqrt{ }$ & & 1 \\
\hline$C A I$ & & $\sqrt{ }$ & $\sqrt{ }$ & & & $\sqrt{ }$ & $\sqrt{ }$ & 4 \\
\hline c. CAI & & $\sqrt{ }$ & $\sqrt{ }$ & & & $\sqrt{ }$ & $\sqrt{ }$ & 4 \\
\hline $\mathrm{RMCl}$ & & $\sqrt{ }$ & $\sqrt{ }$ & & & $\sqrt{ }$ & $\sqrt{ }$ & 4 \\
\hline$R M C I / \sigma_{t}$ & & & & & & & $\sqrt{ }$ & 1 \\
\hline Toplam & & 4 & 5 & - & - & 6 & 6 & 21 \\
\hline
\end{tabular}


Çizelge 10. İki bağımsız değișkenli regresyon eșitliklerinde istatistiksel olarak anlamlı bulunan bağımlı ve bağımsız değișkenler Table 10. Statistically significant dependent and undependent variables in the regression equations with two independent variable

\begin{tabular}{|c|c|c|c|c|c|c|c|}
\hline$\underset{\downarrow}{x_{1}, x_{2}}$ & $\mathrm{TF} / \mathrm{p}$ & $T / p$ & $\mathbf{p}$ & $\mathbf{P}$ & SE & ICR & Toplam \\
\hline RQD & 2 & 1 & - & & 1 & 1 & 6 \\
\hline GSI & - & 1 & & & 1 & - & 2 \\
\hline$\sigma c$ & - & & 1 & & & 1 & 2 \\
\hline E & 2 & 4 & 2 & & 4 & 2 & 15 \\
\hline$\sigma c^{2} / 2 E$ & 1 & & & & & & 1 \\
\hline CAI & 1 & 2 & 2 & & 2 & 3 & 9 \\
\hline$\sigma_{c^{*}} \cdot C A I$ & & 1 & 1 & & 1 & 1 & 4 \\
\hline $\mathrm{RMCl}$ & 2 & 2 & 2 & & 2 & 2 & 10 \\
\hline$R M C l / \sigma_{t}$ & & 1 & & & 1 & 1 & 2 \\
\hline Değișken sayısı & 8 & 12 & 9 & - & 12 & 10 & 51 \\
\hline Anlamlı İfade Sayısı & 4 & 6 & 4 & - & 6 & 5 & 25 \\
\hline
\end{tabular}

Çizelge 11. Üç bağımsız değișkenli regresyon eșitliklerinde istatistiksel olarak anlamlı bulunan bağımlı ve bağımsız değișkenler Table 11. Statistically significant dependent and undependent variables in the regression equations with three independent variable

\begin{tabular}{|c|c|c|c|c|c|c|c|}
\hline $\begin{array}{c}\mathbf{x}_{1}, \mathbf{x}_{2}, \mathbf{x}_{3} \\
\downarrow\end{array}$ & $\mathrm{TF} / \mathrm{p}$ & $T / p$ & p & $\mathbf{P}$ & SE & ICR & Toplam \\
\hline RQD & 1 & 1 & - & - & 1 & 1 & 4 \\
\hline GSI & - & 1 & 1 & - & - & 2 & 4 \\
\hline$\sigma_{c}$ & - & - & - & - & 1 & 2 & 3 \\
\hline$E$ & 1 & 3 & - & - & 2 & 2 & 8 \\
\hline$\sigma_{c}^{2} / 2 E$ & - & - & 1 & - & - & 1 & 2 \\
\hline CAI & - & 1 & 1 & - & 1 & 1 & 4 \\
\hline$\sigma_{c^{\prime}} \cdot C A I$ & - & - & - & - & - & - & - \\
\hline$\sigma_{c} / \sigma_{t}$ & - & - & - & - & - & - & 1 \\
\hline $\mathrm{RMCl}$ & - & - & - & - & 1 & - & - \\
\hline $\mathrm{RMCl} / \sigma_{\mathrm{t}}$ & - & 1 & - & - & - & - & 1 \\
\hline Değișken sayısı & 2 & 7 & 3 & - & 6 & 9 & 27 \\
\hline Anlamlı İfade Sayısı & 1 & 3 & 7 & - & 3 & 8 & 10 \\
\hline
\end{tabular}




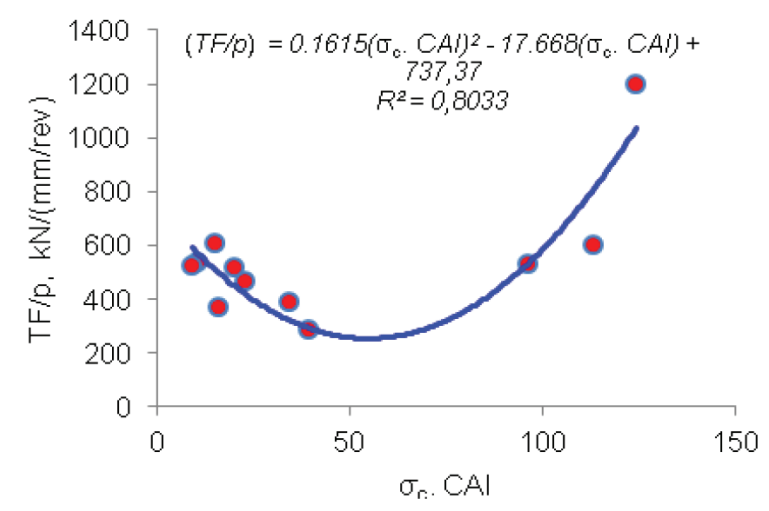

Şekil 4. "Toplam itme kuvveti/penetrasyon" oranı-ile [ $\left.\sigma_{c} . \mathrm{CAl}\right]$ büyüklüğü arasındaki ilișki.

Figure 4 Relationship between "total thrust force/ penetration" ratio and compressive strength $x$ abrasiveness index

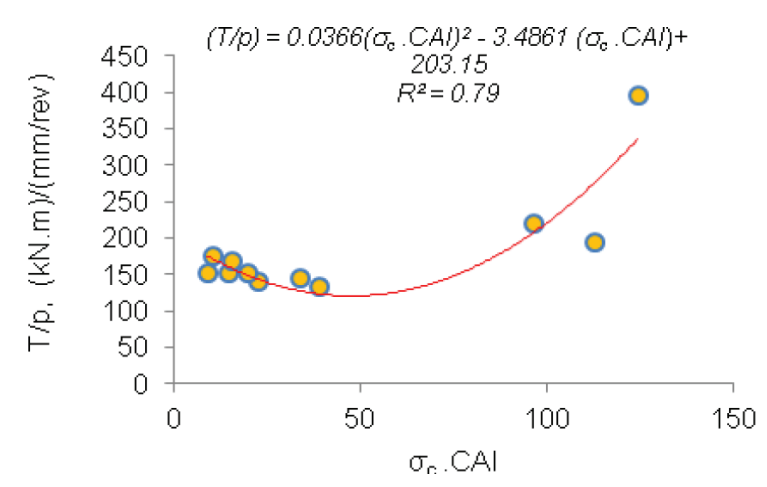

Şekil 5 "Tork/penetrasyon" oranı ile [ $\sigma \mathrm{c}$.CAl] büyüklüğü arasındaki ilişki.

Figure 5 Relationship between "torque/penetration" ratio and $\left[\sigma_{c} \cdot C A l\right]$

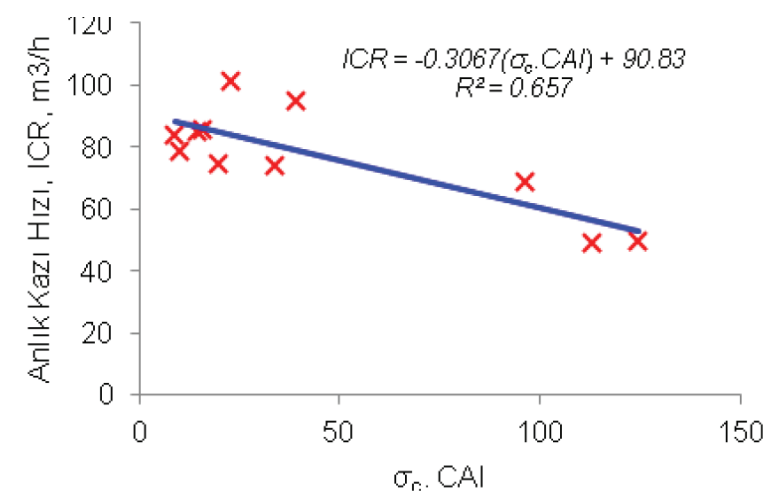

Şekil 6. Anlık kazı hızı ile [ $\left.\sigma_{c} . \mathrm{CAl}\right]$ büyüklüğü arasındaki ilișki.

Figure 6 Relationship between instantaneous cutting rate and $\left[\sigma_{c^{*}} \mathrm{CAl}\right]$

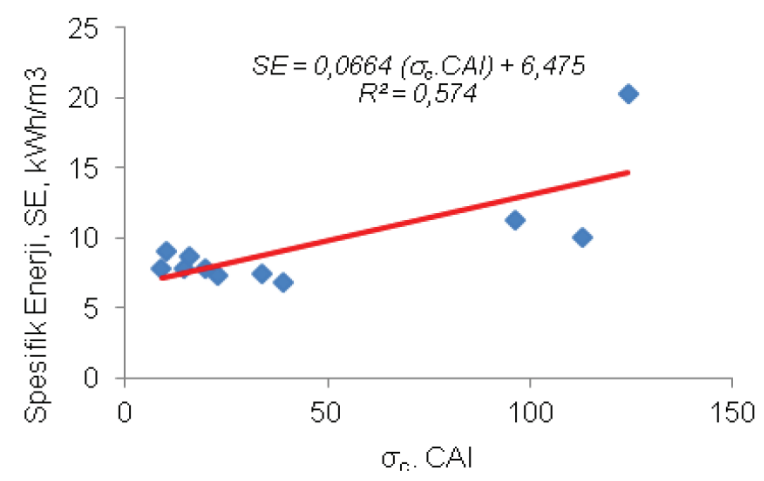

Şekil 7. Spesifik enerji ile [ $\left.\sigma_{c} . \mathrm{CAI}\right]$ büyüklüğü arasındaki ilișki.

Figure 7 Relationship between spesific energy and [ $\left.\sigma_{c} \cdot C A l\right]$

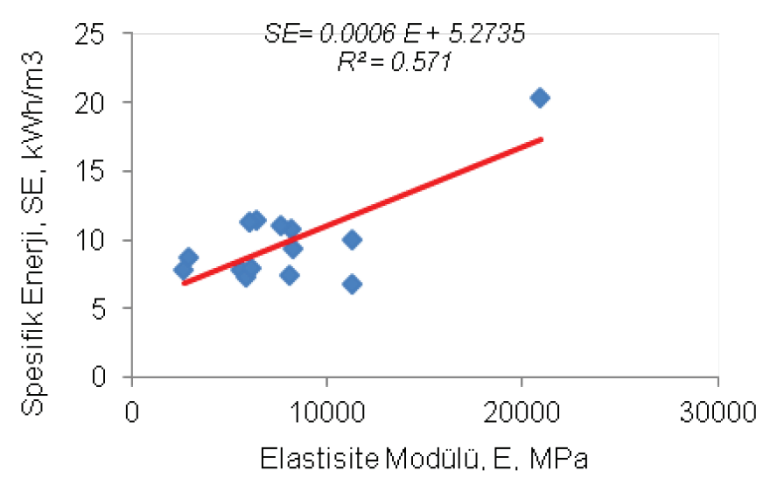

Şekil 8. Spesifik enerji ile elastisite modülü arasındaki ilișki.

Figure 8 Relationship between spesific energy and elasticity modulus

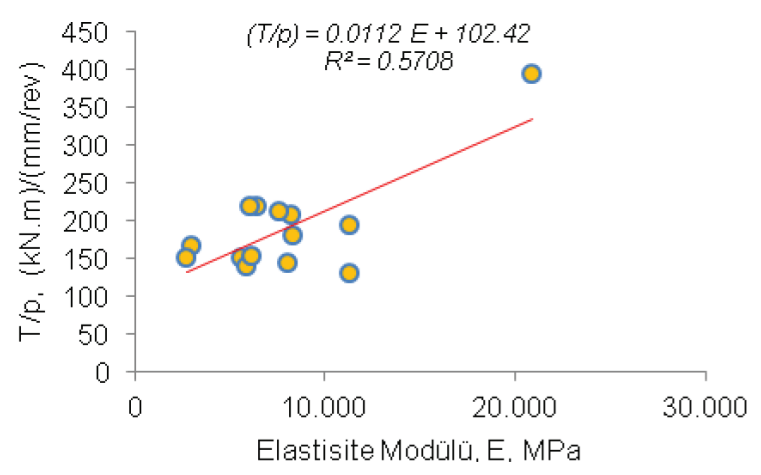

Şekil 9. "Tork/penetrasyon" oranı ile elastisite modülü arasındaki ilișki.

Figure 9 Relationship between "torque/penetration" ratio and elasticity modulus 


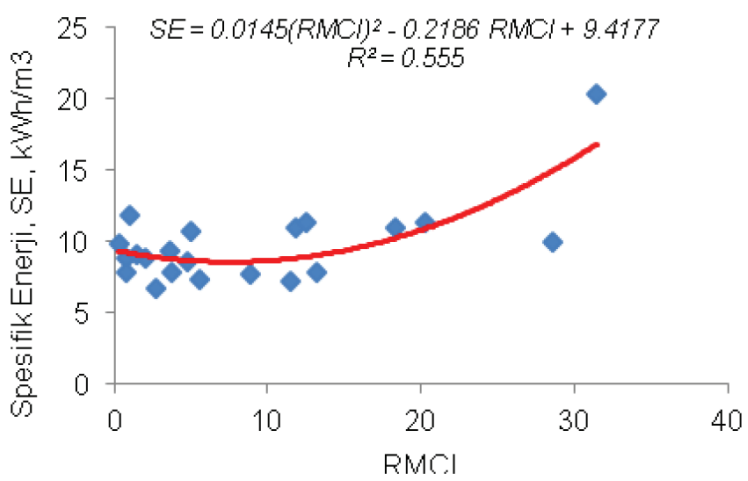

Şekil 10. Spesifik enerji ile kaya kütlesi kesilebilirlik indeksi arasındaki ilișki.

Figure 10 Relationship between spesific energy and rock mass cuttability index

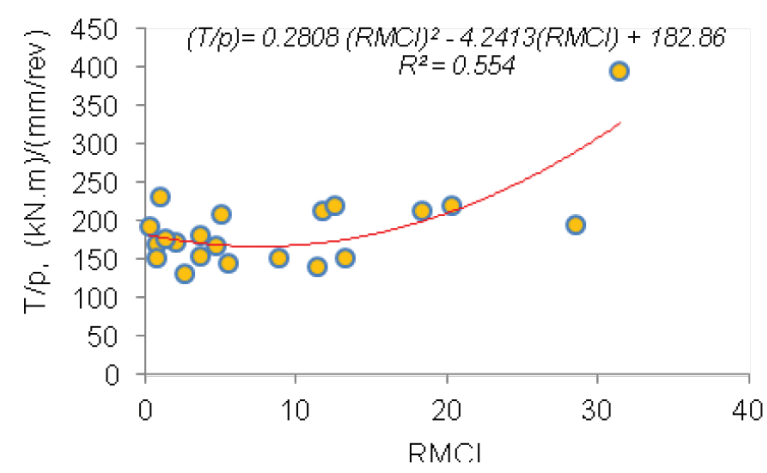

Şekil 11. "Tork/penetrasyon" oranı ile kaya kütlesi kesilebilirlik indeksi arasındaki ilișki.

Figure 11 Relationship between "torque/penetration" ratio and rock mass cuttability index

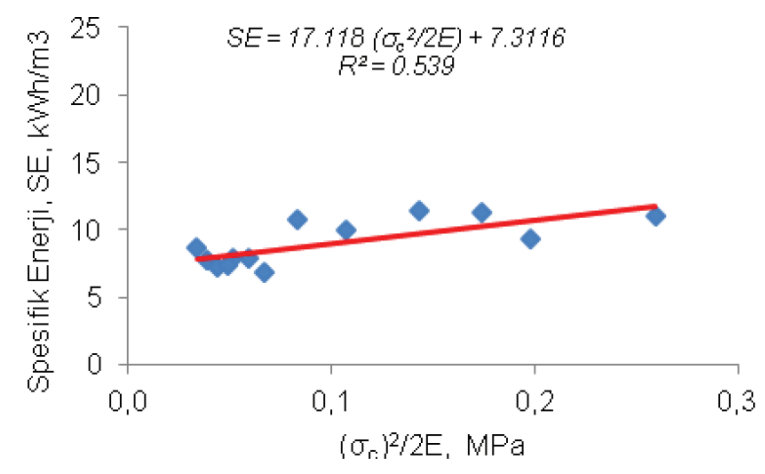

Şekil 12 Spesifik enerji ile $\left[\left(\sigma_{c}\right)^{2} / 2\right.$ E] oranı arasındaki ilișki.

Figure 12 Relationship between spesific energy and [( $\sigma c) 2 / 2 E]$ ratio

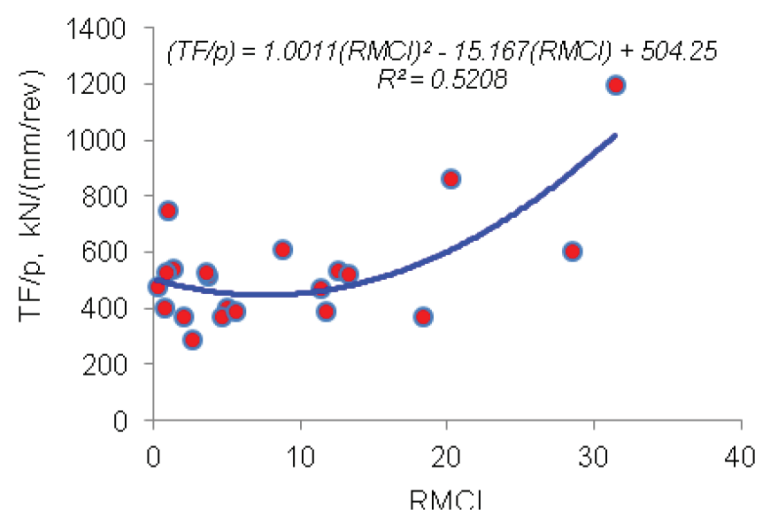

Şekil 13. "Toplam itme kuvveti/penetrasyon" oranı ile kaya kütlesi kesilebilirlik indeksi arasındaki ilișki.

Figure 13 Relationship between "total thrust force/ penetration" ratio and rock mass cuttability index

kayıtları ve bunlardan hesaplanarak türetilen, "toplam itme kuvveti / penetrasyon" oranı, "tork / penetrasyon" oranı, kesme katsayısı, delinebilirlik indeksi, güç tüketimi ve spesifik enerji gibi kazı performans büyüklükleri "bağımlı değișken", jeomekanik özelliker ise "bağımsız değișken" olarak alınmıștır (Çizelge 7, Çizelge 8). Elde edilen ilișkilerin istatistiksel olarak belirli güvenilirlik sınırları içerisinde anlamlı olup olmadığı $\mathrm{F}$ testleri ile (anlam düzeyi $\alpha=0.05$ ) değerlendirilmiștir.

"Tek bağımsız değișkenli" 60 regresyon ifadesi içerisinde 21 adedi istatistiksel olarak anlamlı bulunmuștur (Çizelge 9). Analizler sonucunda, istatistiksel olarak anlamlı en fazla sayıda ilișkiyi spesifik enerji ve anlık kazı hızı büyüklükleri sağlamaktadır. Diğer taraftan jeomekanik özellikler arasında anlamlı olarak en fazla sayıda regresyonu elastisite modülü Cerchar așındırıcllık indeksi, $\left(\sigma_{c^{\prime}} . C A l\right)$ büyüklüğü ve kaya kütlesi kesilebilirlik indeksi sağlamaktadır. Jeolojik dayanım indeksi ile TBM kazı parametreleri arasındaki ilișkiler ise anlamlı bulunmamıștır.

“iki bağımsız değișkenli” 84 adet çoklu doğrusal regresyon modelleri arasında 25 adet regresyon ifadesi istatistiksel olarak anlamlı bulunmuștur (Çizelge 10, Çizelge 12) Kazı Performans parametreleri içerisinde, spesifik enerji, tork / penetrasyon" oranı ve anlık kazı hızı büyüklüleri istatistiksel olarak en fazla sayıda anlamlı 
Çizelge 12. İki bağımsız değișkenli regresyon ifadeleri Table 12. Equations of two undependent variables

\begin{tabular}{|c|c|c|}
\hline Eșitlik & $\begin{array}{c}\text { Korelasyon } \\
\text { katsayısı }\end{array}$ & $\begin{array}{c}\text { Eșitlik } \\
\text { No }\end{array}$ \\
\hline$I C R=\left(19.5310^{-3}\right) E-0,367\left(\sigma_{c} \cdot C A I\right)$ & $r=0.866$ & (9) \\
\hline$p=\left(34510^{-3}\right) E-0.576\left(\sigma_{c} C A I\right)$ & $r=0.858$ & (10) \\
\hline$\frac{T}{p}=0.0069 E+0.741\left(\sigma_{c} C A I\right)$ & $r=0.831$ & (11) \\
\hline$S E=\left(35.610^{-3}\right) E-0.0381\left(\sigma_{c} C A I\right)$ & $r=0.831$ & (12) \\
\hline$\frac{T}{p}=0.0007 E+2.917 R M C I$ & $r=0.823$ & (13) \\
\hline$S E=\left(36.110^{-3}\right) E-0.150 R M C I$ & $r=0.823$ & (14) \\
\hline$S E=1.904 C A I+0.049\left(\frac{R M C I}{\sigma_{t}}\right)$ & $r=0.820$ & (15) \\
\hline$I C R=-14.968 C A I-2.673\left(\frac{R M C I}{\sigma_{t}}\right)$ & $r=0.820$ & (16) \\
\hline$\frac{T}{p}=36.962 C A I+0.947\left(\frac{R M C I}{\sigma_{t}}\right)$ & $r=0.819$ & (17) \\
\hline$p=-1.539 C A I-0.109 R M C I$ & $r=0.803$ & (18) \\
\hline
\end{tabular}

ilișkiye sahiptir. Diğer taraftan, anlamlı regresyon modelleri içerisinde jeomekanik büyüklükler açısından sıralama elastisite modülü, kaya kütlesi kesilebilirlik indeksi, Cerchar așındırıcılık indeksi ve $R Q D$ șeklindedir.

"Üç bağımsız değișkenli" 84 adet çoklu doğrusal regresyon modeli arasında ise sadece 10 ilișki istatistiksel olarak anlamlı bulunmuștur (Çizelge 11, Çizelge 13). Üç değișkenli çoklu regresyon ifadelerinde, TBM kazı parametreleri içerisinde anlık kazı hızı ve spesifik enerji en fazla sayıda anlamlı ilișkiye sahiptir. Jeomekanik özellikler açısından sıralama, iki değișkenli modellerden biraz farklı olarak, elastisite modülü, Cerchar așındırıcılık indeksi $R Q D$ ve GSI șeklindedir.

Elde edilen bu istatistiksel ilișkilerin pratik faydası, benzer jeolojik formasyonlarda ve jeomekanik özelliklere sahip kaya ortamlarda TBM ile açllacak tünellerde, tüneller açılmadan önce yapılacak sondaj çalıșmalarından elde edilecek jeomekanik parametreler kullanılarak TBM kazı performansının belirli bir yaklașıklılık içerisinde tahmin edilmesi olacaktır. Bu kestirimler kazı makinesi seçimine ıșık tutacağı gibi, projenin kazı planlamasında yararlı olacaktır. TBM kazı uygulamalarından elde edilecek verilerin toplanması ve değerlendirilmesi ile sondajlardan elde edilecek jeomekanik veriler kullanılarak yapılacak performans tahminleri daha gerçekçi .olacaktır.

\section{KATKI BELIRTME}

Yazarlar bu çalıșmadaki teșvik ve değerli akademik katkılarından dolayı Prof. Dr. Ergin Arığlu (Yapı Merkezi Holding A.Ș.)'na ve Prof Dr. Reșat Ulusay'a teșekkürlerini sunarlar. Çalıșmada yer verilen görüș ve değerlendirmeler yazarlarına ait olup herhangi bir kurum ve kurulușu bağlamaz. 
Çizelge 13. Üç bağımsız değișkenli regresyon ifadeleri Table 13. Equations of three undependent variables

\begin{tabular}{|c|c|c|}
\hline Eșitlik & $\begin{array}{c}\text { Korelasyon } \\
\text { katsayısı }\end{array}$ & Eșitlik No \\
\hline$S E=\left(26.410^{-3}\right) E-2.632 C A I-0.016\left(\frac{R M C I}{\sigma_{t}}\right)$ & $r=0.951$ & (19) \\
\hline$\frac{T}{p}=-\left(5.12810^{-3}\right) E+51.11 C A I+0.309\left(\frac{R M C I}{\sigma_{t}}\right)$ & $r=0,950$ & (20) \\
\hline$I C R=0.896 G S I-37.416 C A I+189.804\left(\frac{\sigma_{c}^{2}}{2 E}\right)$ & $r=0,917$ & (21) \\
\hline$p=0.141 G S I-5.842 C A I+29.373\left(\frac{\sigma_{c}^{2}}{2 E}\right)$ & $r=0,910$ & (22) \\
\hline$\frac{T}{p}=1.020 R Q D+0.943 \sigma_{c}+\left(7.68 \cdot 10^{-3}\right) E$ & $r=0,801$ & (23) \\
\hline$S E=0.053 R Q D+0.049 \sigma_{c}+\left(39.6 \cdot 10^{-3}\right) E$ & $r=0,801$ & (24) \\
\hline$S E=0.033 G S I+0.044 \sigma_{c}+\left(47.0 \cdot 10^{-3}\right) E$ & $r=0,801$ & (25) \\
\hline$\frac{T}{p}=0.640 G S I+0.858 \sigma_{c}+\left(9.12310^{-3}\right) E$ & $r=0,776$ & (26) \\
\hline$\frac{T F}{p}=6.946 R Q D-0.463 \sigma_{c}+0.0224 E$ & $r=0,746$ & (27) \\
\hline$I C R=-0.241 R Q D-0.379 \sigma_{c}-\left(88.310^{-3}\right) E$ & $r=0,726$ & (28) \\
\hline
\end{tabular}

\section{KAYNAKLAR}

Barton, N.R.; Lien, R.; Lunde, J., 1974. Engineering classification of rock masses for the design of tunnel support. Rock Mechanics and Rock Engineering, 6 (4): 189-236.

Barton, N. 2000. TBM tunneling in jointed and faulted rock. A.A. Balkema, Rotterdam.

Bieniawski, Z., T., Celada, B., Galera J., M. ve Alvarez, M. 2006. Rock mass excavability (RME) indicator: new way to selecting the optimum tunnel construction method. Proceedings of the ITA-AITES World Tunneling Congress, Seoul, Korea, pp. 15-23.

Bilgin N., Balcı, C., Tunçdemir, H., Eskikaya, Ș. Akgül, M. and Algan, M., 1999. The perfomance prediction of a TBM in difficult ground condition. AFTES, Journees d'Etudes Internationales de Paris, October, pp.115-121.

Farrokh, E., Rostami, J. and Laughton, C. 2012. Study of various models for estimation of penetration rate of hard rock TBMs. Tunnelling and Underground Space Technology, 30, 110-123.

Graham, P. C. 1976. Rock exploration for machine manufacturers. Proceeding of the Symposium on Exploration for Rock Engineering, 173-180.

Hassanpour, J., Rostami, J., Kamehchiyan, M., Bruland, A. and Tavakoli, H.R. 2009. TBM performance analysis karaj water conveyance tunnel. Rock Mechanics and Rock Engineering, 43 (4), 427-445.

Kato, M. 1971. Construction machinery. Gihodo, Tokyo, 348-349. 
Ketin, İ. 1992. İstanbul ve dolayının jeoloji haritası. iSKi (Yayınlanmamıș çalıșma) İstanbul.

Kodamanoğlu, T. 1977. İstanbul-Beykoz civarının jeolojik incelenmesi: MTA Dergisi, Sayı 88, s. 32-43, Ankara.

Lin, C., C. and Yu C., W. 2005. Discussion and solution of the TBM trapped in the westbound hseuehshan tunnel. Proceeding of the World Long Tunnels 2005 Congress, Taipei, Taiwan, pp. 383-394.

Lui, H., S. and Chang, L., C. 2005. Examination of the TBM selection and its effect in the hsuehshan tunnel. Proceeding of the World Long Tunnels 2005 Congress, Taipei, Taiwan, pp. 23-33.

Nelson, P. P., Ingraffea, A. R., O’Rourke, T. D. 1985. TBM performance prediction using rock fracture parameters, International Journal of Rock Mechanics and Mining Sciences, 22, 189-192

Okubo, S., Fukuki, K. ve Chen W. 2003. Expert system for applicability of tunnel boring machines in Japan. Rock Mechanics and Rock Engineering, 36 (4), 305-322.

Oraee, K., Salhi, B. and Sarkissian, A., 2010 TBM performance prediction in Iran. Tunnel \& Tunneling International, May 2010 51-54.

Özdemir, L. 1977. Development of theoretical equations for predicting tunnel borability. Ph. D. Thesis, Colorado School of Mines, Golden.Co.

Rostami, J. and Ozdemir, L. 1993. A new model for performance prediction of hard rock TBMs.Proceeding of the RETC, 793809

Roxborough, F. F. and Phillips, H. R. 1975. Rock excavation by disc cutter. International Journal of Rock Mechanics and Mining Sciences, 12, 361-366.

Saito, T., Shimada, T., Yoshikawa, K. and Tukioka, A. 1971. Mechanized tunnel excavation. Sankaido, Tokyo, 36-81.

Sanio, H. P. 1985. Prediction of the performance of disc cutters in anisotropic rock. International Journal of Rock Mechanics and Mining Sciences, 22, 153-161.
Sapigni, M., Berti, M., Bethaz, E., Busillo, A. and Cardore, G. 2002. TBM performance estimation using rock mass classification. International Journal of Rock Mechanics and Mining Sciences, 39, 771-788.

Seymen, i. 1995. İzmit Körfezi ve çevresinin jeolojisi, İzmit Körfezi Kuvarterner İstifi. (Edt. Meriç, E), Kocaeli Valiliği Çevre Koruma Vakfı, Kocaeli

Snowdon, R. A., Ryley, M. D., Temporal, J. 1982. A study of disc cutting in selected British rocks, International Journal of Rock Mechanics and Mining Sciences, 19, 107-121.

Sönmez, H., Ulusay, R., 2002. A discussion on the Hoek-Brown failure criterion and suggested modifications to the criterion verified by slope stability case studies. Yerbilimleri, 26, 77-99.

Yüksel, A., Sözak, N. ve Gülle, G. 2005. Kadıköy Kartal Raylı Toplu Tașıma Sistemi Mühendislik Jeolojisi Raporu, Rapor No: KK-GE-TR-GN-004, Yapı Merkezi Yüksel - Doğuș - Yenigün İnșaat Ortak Girișimi, İstanbul

Yüksel, A., Yeșilçimen, Ö., Arıoğlu, E. 2006: Kadıköy-Kartal Raylı Toplu Tașıma Sistemi Projesinde Jeolojik ve Jeoteknik Araștırma Çalıșmaları, Rocmec'2006, VIII Bölgesel Kaya Mekaniği Sempozyumu, İstanbul, s. 157-170.

Yüksel, A., 2013. TBM Makinelerinde Kayaç Özellikleri ve Makro Süreksizliklerin Kazı Performansına Etkilerinin Araștırılması, Doktora Tezi, iTü Fen Bilimleri Enstitüsü Maden Mühendisliği Programı, İstanbul. 